\title{
Relationship between sedimentary organic matter and benthic fauna within the Gulf of Lion: synthesis on the identification of new biochemical descriptors of sedimentary organic nutritional value
}

\section{Relation liant la matière organique sédimentée et la faune benthique dans le golfe du Lion : synthèse sur l'identification de nouveaux descripteurs biochimiques de la valeur nutritive de la matière organique particulaire sédimentée}

\author{
Antoine Grémare *, Laurence Medernach, Francis DeBovee, Jean-Michel Amouroux, \\ François Charles, Alain Dinet, Gilles Vetion, Philippe Albert, Jean-Charles Colomines \\ Observatoire Océanologique de Banyuls, Laboratoire d'Océanologie Biologique, UMR 7621, Université Pierre et Marie Curie, \\ CNRS-INSU, BP 44, 66651 Banyuls-sur-Mer cedex, France
}

Received 4 October 2001; received in revised form 12 January 2002; accepted 18 January 2002

\begin{abstract}
The abilities of several biochemical characteristics of sedimentary organic matter to describe quantitative changes in benthic fauna were assessed based on several surveys carried out within the Gulf of Lion during the last decade. Two sets of high frequency samplings were carried out both inshore and offshore, together with an assessment of seasonal variability along a depth gradient, and a synoptic assessment of mesoscale spatial variability. The considered biochemical parameters were: total organic matter, organic carbon, nitrogen, total proteins, available proteins, carbohydrates, lipids, total and available amino acids. The considered faunal parameters were the abundance and the biomass of both meio- and macrofauna. Our results contribute to unravel the relative importance of food digestibility and composition in controlling particulate organic matter nutritional value. Spectra of both total and available amino acids were almost constant irrespective of the seasons and/or the environments, which were studied during these surveys. This underlines the role of particulate organic matter digestibility relative to its ability to meet specific nutritional requirements in controlling benthic fauna. Multivariate analysis used to relate biochemical and faunal parameters suggest that available amino acids and lipids are the best descriptors of food nutritional value. In contrast with carbohydrates, these two parameters are both associated with the most labile fraction of particulate organic matter. This result suggests that the use of the sum of proteins, carbohydrates and lipids as a proxy for labile organic matter is precluded at least in areas similar to the Gulf of Lion.
\end{abstract} (C) 2003 Published by Éditions scientifiques et médicales Elsevier SAS.

\section{Résumé}

Les aptitudes de plusieurs des caractéristiques biochimiques de la matière organique particulaire sédimentée à décrire les changements quantitatifs de la faune benthique ont été comparées à partir des résultats de plusieurs campagnes de prélèvements ayant eu lieu dans le golfe du Lion au cours de ces dix dernières années. Ces travaux ont consisté en deux suivis haute fréquence conduits à une station littorale et à une station du large, en une évaluation de la variabilité saisonnière le long d'un gradient côte large, et, enfin, en une étude synoptique de la variabilité spatiale à mesoéchelle. Les paramètres biochimiques considérés sont la matière organique totale, le carbone organique, l'azote, les protéines totales, les protéines disponibles, les sucres, les lipides, les acides aminés totaux et les acides aminés disponibles. Les paramètres faunistiques considérés sont l'abondance et la biomasse de la meio- et de la macrofaune. Les résultats obtenus contribuent à délimiter l'importance relative de la digestibilité et de l'aptitude à satisfaire les besoins nutritionnels dans la définition de la valeur nutritive de la matière

* Corresponding author. Fax: +33-4-68-88-73-95.

E-mail address: gremare@obs-banyuls.fr (A. Grémare). 
organique particulaire sédimentée. Ainsi, la constance des spectres en acides aminés totaux et disponibles quels que soient les environnements et les saisons étudiés, suggère-t-elle un plus grand rôle de la digestibilité de la matière organique particulaire que de son aptitude à satisfaire des besoins nutritionnels spécifiques dans le contrôle de la faune benthique. Par opposition aux sucres, les lipides et les acides aminés disponibles sont associés à la fraction la plus labile de la matière organique particulaire. Ceci rend inopérant l'usage de la somme des concentrations en protéines, sucres et lipides en tant qu'indice de la fraction labile de la matière organique, au moins dans les zones directement comparables au golfe du Lion.

(C) 2003 Published by Éditions scientifiques et médicales Elsevier SAS.

Keywords: Sedimentary organics; Benthos; Gulf of Lion; Amino acids; Bioavailability

Mots clés : Matière organique sédimentée ; Benthos ; golfe du Lion ; Acides aminés ; Biodisponibilité

\section{Introduction}

The fate of sedimented particulate organic matter (POM) is influenced by the benthic fauna both through nutrition (Cammen, 1980) and bioturbation (Webb, 1969; Luckenback, 1986). Once sedimented some of the POM is channelled into the trophic network and then mineralised by microbes (Moriarty et al., 1985; Findlay et al., 1990; Alkemade et al., 1992) or benthic primary consumers (Charles et al., 1995). Other fractions are either resuspended or buried within the sediments at rates highly depending on the resident infauna (Bianchi, 1988; Blair et al., 1996; Levin et al., 1997). Relationships between POM and benthic fauna are thus bilateral. Benthic invertebrates significantly affect the fate of sedimented POM. On the other hand, they also depend on the amount and the nature of the available POM, which constitutes their main food source (Marsh and Tenore, 1990; Graf, 1992). This last aspect is essential in view of describing the response of benthic ecosystems to changes in vertical particle fluxes.

A classical approach in this type of study consists in correlating the amount of sedimentaryorganics with quantitative characteristics of benthic fauna (Soltwedel and Thiel, 1995; Relexans et al., 1996). This raises the problem of the unit that should be used to assess sedimentary organics. Secondary production indeed results from the whole nutrition process, which is composed of separate stages, namely: ingestion, absorption and assimilation. Selectivity is associated to ingestion in many benthic primary consumers including both suspension (Riisgård, 1988) and deposit-feeders (Jumars et al., 1982; Grémare, 1988). Absorption is only dealing with the fraction of the ingested POM, which is hydrolysed by gut enzymes and/or surfactants (Plante and Jumars, 1992; Mayer et al., 1995; Plante and Shriver, 1998). Assimilation, which corresponds to the final incorporation of POM constituents in the animal tissues, is highly depending on the meeting of specific nutritional requirements (Phillips, 1984). Because nutrition results from a sequence of processes, which do not affect the whole pool of sedimented POM, there is only little hope in trying to correlate benthic secondary production or standing stock with bulk descriptors of sedimentary organics. It is, therefore, essential to identify more specific biochemical parameters, which could account for the fraction of sedimented POM that can indeed be used by benthic invertebrates.

Since selectivity during ingestion may vary among taxa and/or feeding types (Whitlatch and Weinberg, 1982; Dobbs and Scholly, 1986), the first step of this approach consists in assessing the relative importance of digestibility and of the ability to meet nutritional requirements of benthic fauna. Nitrogen is often supposed to be limiting in the benthic trophic network, either due to a bulk deficiency, or to a lack of some essential amino acids (Marsh and Tenore, 1990). Specific extraction procedures have thus been recently developed to assay the bioavailable amounts of individual amino acids by mimicking processes taking place within the gut of benthic invertebrates (Mayer et al., 1986, 1995). Under these assumptions, we have focused our attention on the biochemical analysis of the nitrogenous fraction of sediment organic matter. Our specific objectives were to: (1) determine what is more important between digestibility and ability to meet nutritional requirements in determining sedimentary organic nutritional value, and (2) try to identify new biochemical descriptors of sedimentary organic nutritional value based on their ability to describe changes in quantitative characteristics of benthic fauna.

\section{Materials and methods}

The French National Program on Coastal Oceanography (Pnoc) and then the French National Program on Coastal Environment (Pnec) provided us with a unique opportunity to address these questions within the Gulf of Lion. The hydrology of this area is dominated by the liguro-provencal current. Its main branch flows southwestward along the continental slope (Millot, 1990). Because of its presence, particles inputs from the Rhône river are mainly maintained on the continental shelf where they are submitted to several deposition/resuspension cycles while drifting southwestward due to the intrusion of the shallow branch of the liguroprovençal current. These particles are then transferred to the deep sea, mostly via submarine canyons (Durrieu de Madron et al., 1990; Monaco et al., 1999). This pattern of particle transfer enhances spatial heterogeneity (i.e. between the eastern and the western part of the Gulf, and between submarine canyons and surrounding areas) in both the amount and the 
nutritional value of sedimented organic matter (Buscail and Germain, 1997). Temporal changes in both sedimentary and meiofauna characteristics are mainly cued by primary production and seasonal changes in the meteorological regime, which controls both continental inputs and sediment resuspension (DeBovée et al., 1990). Because of such spatial and temporal variability, the Gulf of Lion constitutes an especially suitable environment for the study of the interactions between sedimented organic matter and benthic fauna.

During the last decade, we have been studying the interactions between sedimentary organics and benthic fauna in the Gulf of Lion following several complementary sampling strategies. The locations of all the sampled sites are given in Fig. 1. Their main characteristics (i.e. depth and distance to the coast) are reported in Table 1 together with the corresponding sampling dates.

High frequency changes of gross sedimentation rates (GSR) in the littoral zone have been assessed between June 1992 and 1996 at a permanent site $\left(42^{\circ} 29^{\prime} 08^{\prime \prime} \mathrm{N}\right.$ and $03^{\circ} 08^{\prime} 42^{\prime \prime}$ E) located within the Bay of Banyuls-sur-Mer (Pnoc cruises). Two sediment traps were moored at this station and collected weekly between June 1992 and 1996. These traps consisted of polyethylene pipes prolonged by a cone and a collector (Charles, 1994). The inner diameter of the pipe was $40 \mathrm{~cm}$ with a total height of $190 \mathrm{~cm}$ giving an aspect ratio of 4.75 . The mouths of the traps were located $3 \mathrm{~m}$ above the sediment surface. The collected material was assayed for total organic matter, organic carbon, nitrogen, total proteins (TPRT), available proteins (APRT), carbohydrates, lipids, total amino acids (THAA), and enzymatically hydrolysable (i.e. available) amino acids (EHAA). We did not fix sediment trap materials because of preliminary trials,

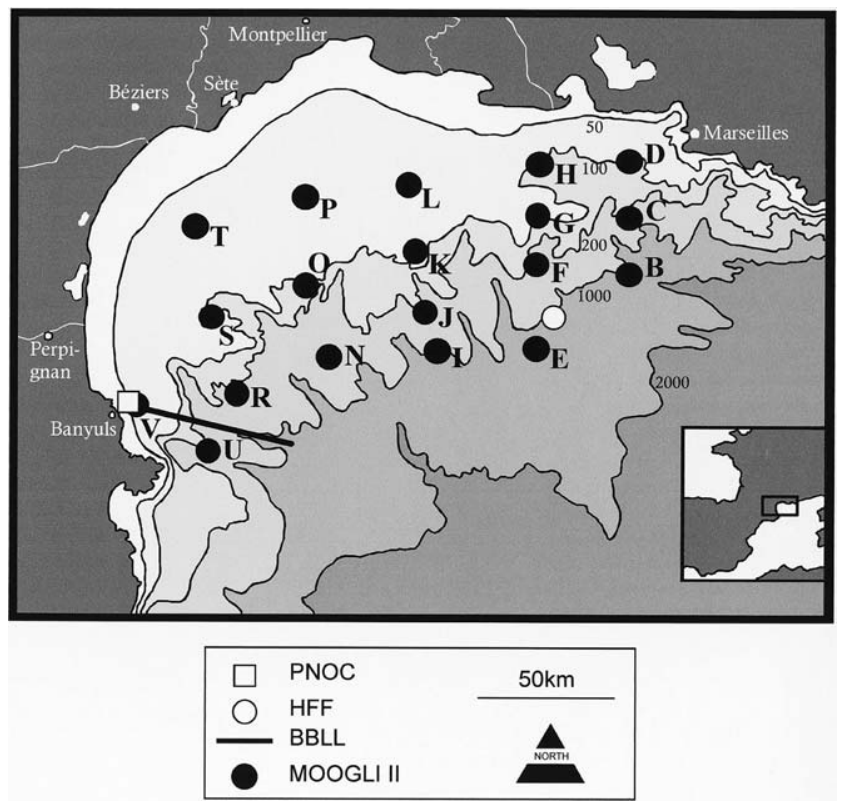

Fig. 1. Map showing the localisation of all the studied sites. Fig. 1. Carte montrant la position de tous les sites étudiés. which showed that the use of preservative did not allow for the assessment of APRT and EHAA due to the enzymatic digestion step (Grémare, unpublished). It nevertheless should be stressed that temporal changes in the composition of sedimenting POM may thus have been slightly underestimated due to faster degradation of POM labile components. Total organic matter was assessed by measuring the weight loss after combustion $\left(450{ }^{\circ} \mathrm{C}\right.$ during $\left.5 \mathrm{~h}\right)$. Organic carbon and nitrogen contents were measured after acidification $(\mathrm{HCl}$ $1 \mathrm{~N}$ in excess) using a CHN Perkin Elmer 2400 analyser. TPRT were measured using the Lowry procedure (Lowry et al., 1951) as modified by Rice (1982) to account for the reactivityof phenolic compounds. APRT were assayed using the procedure proposed by Mayer et al. (1986). Carbohydrates were assayed after Dubois et al. (1956). Lipids were assayed using the procedure of Barnes and Blackstock (1973).

In order to assess THAA, $15 \mathrm{mg}$ DW of sediment were submitted to a strong acid hydrolysis $(500 \mu \mathrm{l}$ of $6 \mathrm{~N} \mathrm{HCl}$, $100{ }^{\circ} \mathrm{C}, 24 \mathrm{~h}$, under vacuum). Subsamples $(0.4 \mathrm{ml})$ of the hydrolysates were neutralised with $0.4 \mathrm{ml}$ of $6 \mathrm{~N} \mathrm{NaOH}$ and buffered with $0.8 \mathrm{ml}$ of $\mathrm{H}_{3} \mathrm{BO}_{3}(0.4 \mathrm{M}, \mathrm{pH}$ 8). Fluorescent derivatives were obtained by adding $6 \mu$ l of an orthophtaldialdehyde solution ( $125 \mathrm{mg}$ in $2.5 \mathrm{ml}$ of methanol and $0.125 \mathrm{ml}$ of mercaptoethanol) and $400 \mu \mathrm{l}$ of $\mathrm{H}_{3} \mathrm{BO}_{3}$ to $100 \mu \mathrm{l}$ of those samples. THAA identification was based on retention times within an HPLC column and achieved through comparison with a standard containing 19 amino acids. THAA quantification was based on fluorescence measurements (excitation wavelength: $335 \mathrm{~nm}$, emission wavelength: $450 \mathrm{~nm}$ ). Homoserine and $s$-methyl cysteine were both used as internal standards.

EHAA were extracted following the biomimetic approach proposed by Mayer et al. (1995). One hundred milligram DW of sediment were poisoned with $1 \mathrm{ml}$ of a solution containing two inhibitors of bacterial active transport systems $(0.1 \mathrm{M}$ sodium arsenate and $0.1 \mathrm{mM}$ pentachlorophenol within a pH 8 sodium phosphate buffer). This mixture was let to incubate for $1 \mathrm{~h}$ at room temperature. One hundred microlitre of proteinase $\mathrm{K}$ solution $\left(1 \mathrm{mg} \mathrm{ml}^{-1}\right)$ were then added and the samples were incubated for $6 \mathrm{~h}$ at $37{ }^{\circ} \mathrm{C}$. They were then centrifuged to discard remaining particulate material. Seventy-five millilitre of pure TCA were added to $750 \mu$ of supernatant to precipitate macromolecules, which are considered to be non-suitable for absorption. Seven hundred and fifty microlitre of the supernatant were then hydrolysed and processed as described for THAA. In addition, a blank accounting for possible degradation of the enzyme was carried out.

High frequency changes in sedimentary organic biochemical characteristics were assessed at an offshore site (42 $\left.41^{\prime} 20^{\prime \prime} \mathrm{N}, 4^{\circ} 50^{\prime} 06^{\prime \prime} \mathrm{E}\right)$ between 31 March and 1 May 1997 (HFF cruises). At each sampling date, sediment cores (9 $\mathrm{cm}$ in diameter) were taken using a Bowers and Conolly midicorer (Ocean Scientific ${ }^{\circledR}$ ). This instrument is designed to take four undisturbed cores at a time from the seabed. The 
Table 1

Sampling dates, geographic coordinates, depth $(Z)$ and distances from the coast $(D)$ of the sampling stations. * Only sampled for macrofauna. The last two digits of the latitude and longitude data refer to percent of minute. PNOC: Programme National d'Océanographie Côtière, HFF: high frequency flux, BBLL: Banyuls Benthic Lander in the Gulf of Lion, Moogli II: Modélisation et Observation dans le golfe du Lion

Dates d'échantillonnage, coordonnées géographiques, profondeurs (Z) et distances à la côte (D) des stations échantillonnées lors de la présente étude.* station seulement échantillonnée pour la macrofaune. Les deux derniers chiffres des latitudes et des longitudes correspondent à des centièmes de minute. PNOC: Programme National d'Océanographie Côtière, HFF: High Frequency Flux, BBLL: Banyuls Benthic Lander in the Gulf of Lions, Moogli II: Modélisation et observation dans le golfe du Lion

\begin{tabular}{|c|c|c|c|c|c|c|}
\hline Surveys & Stations & Date & Latitude N & Longitude E & $Z(\mathrm{~m})$ & $D(\mathrm{~km})$ \\
\hline PNOC & PNOC & 06/92-06/96 & $42^{\circ} 29^{\prime} 08^{\prime \prime}$ & $03^{\circ} 08^{\prime} 42^{\prime \prime}$ & 17 & 0.4 \\
\hline \multirow[t]{4}{*}{ HFF } & HFF & $31 / 03 / 97$ & $42^{\circ} 41^{\prime} 20^{\prime \prime}$ & $4^{\circ} 50^{\prime} 06^{\prime \prime}$ & 1266 & 71.5 \\
\hline & & $11 / 04 / 97$ & & & & \\
\hline & & $19 / 04 / 97$ & & & & \\
\hline & & 01/05/97 & & & & \\
\hline \multirow[t]{18}{*}{ BBLL } & VTC & 07/02/97 & $42^{\circ} 29^{\prime} 68^{\prime \prime}$ & $03^{\circ} 09^{\prime} 63^{\prime \prime}$ & 35 & 2.0 \\
\hline & & $12 / 08 / 97$ & & & & \\
\hline & & 06/05/98 & & & & \\
\hline & & $01 / 12 / 98$ & & & & \\
\hline & VL & $07 / 02 / 97$ & $42^{\circ} 30^{\prime} 56^{\prime \prime}$ & $03^{\circ} 12^{\prime} 94^{\prime \prime}$ & 86 & 6.1 \\
\hline & & $10 / 08 / 97$ & & & & \\
\hline & & 03/05/98 & & & & \\
\hline & & 28/11/98 & & & & \\
\hline & INT1 & 08/02/97 & $42^{\circ} 25^{\prime} 58^{\prime \prime}$ & $03^{\circ} 41^{\prime} 94^{\prime \prime}$ & 800 & 33.3 \\
\hline & & 09/08/97 & & & & \\
\hline & & 08/05/97 & & & & \\
\hline & INT2 & $10 / 02 / 97$ & $42^{\circ} 29^{\prime} 40^{\prime \prime}$ & $03^{\circ} 29^{\prime} 87^{\prime \prime}$ & 320 & 24.1 \\
\hline & & $13 / 08 / 97 *$ & & & & \\
\hline & & 09/05/98 & & & & \\
\hline & AXE & $04 / 02 / 97$ & $42^{\circ} 27^{\prime} 60^{\prime \prime}$ & $03^{\circ} 29^{\prime} 84^{\prime \prime}$ & 920 & 21.5 \\
\hline & & 08/08/97 & & & & \\
\hline & & 08/05/98 & & & & \\
\hline & B & 04/06/98 & $42^{\circ} 55^{\prime} 23^{\prime \prime}$ & $05^{\circ} 08^{\prime} 33^{\prime \prime}$ & 1200 & 37.0 \\
\hline \multirow[t]{18}{*}{ MOOGLI II } & $\mathrm{C}$ & 04/06/98 & $43^{\circ} 04^{\prime} 06^{\prime \prime}$ & $05^{\circ} 07^{\prime} 50^{\prime \prime}$ & 157 & 24.1 \\
\hline & D & 05/06/98 & $43^{\circ} 15^{\prime} 05^{\prime \prime}$ & $05^{\circ} 07^{\prime} 95^{\prime \prime}$ & 78 & 9.3 \\
\hline & E & $15 / 06 / 98$ & $42^{\circ} 40^{\prime} 00^{\prime \prime}$ & $04^{\circ} 45^{\prime} 00^{\prime \prime}$ & 1380 & 75.9 \\
\hline & $\mathrm{F}$ & 05/06/98 & $42^{\circ} 54^{\prime} 91^{\prime \prime}$ & $04^{\circ} 44^{\prime} 95^{\prime \prime}$ & 240 & 46.3 \\
\hline & G & 05/06/98 & $43^{\circ} 04^{\prime} 02^{\prime \prime}$ & $04^{\circ} 44^{\prime} 96^{\prime \prime}$ & 95 & 29.6 \\
\hline & $\mathrm{H}$ & 05/06/98 & $43^{\circ} 14^{\prime} 97^{\prime \prime}$ & $04^{\circ} 44^{\prime} 96^{\prime \prime}$ & 75 & 11.1 \\
\hline & I & $17 / 06 / 98$ & $42^{\circ} 39^{\prime} 98^{\prime \prime}$ & $04^{\circ} 22^{\prime} 99^{\prime \prime}$ & 830 & 79.6 \\
\hline & $\mathrm{J}$ & 06/06/98 & $42^{\circ} 44^{\prime} 97^{\prime \prime}$ & $04^{\circ} 19^{\prime} 04^{\prime \prime}$ & 340 & 72.2 \\
\hline & K & 06/06/98 & $42^{\circ} 59^{\prime} 01^{\prime \prime}$ & $04^{\circ} 14^{\prime} 91^{\prime \prime}$ & 94 & 51.9 \\
\hline & $\mathrm{L}$ & 06/06/98 & $43^{\circ} 12^{\prime} 01^{\prime \prime}$ & $04^{\circ} 13^{\prime} 02^{\prime \prime}$ & 87 & 27.8 \\
\hline & $\mathrm{N}$ & 07/06/98 & $42^{\circ} 20^{\prime} 01^{\prime \prime}$ & $03^{\circ} 35^{\prime} 01^{\prime \prime}$ & 380 & 22.2 \\
\hline & $\mathrm{O}$ & 07/06/98 & $42^{\circ} 54^{\prime} 35^{\prime \prime}$ & $03^{\circ} 51^{\prime} 90^{\prime \prime}$ & 92 & 50.0 \\
\hline & $\mathrm{P}$ & 07/06/98 & $43^{\circ} 07^{\prime} 00^{\prime \prime}$ & $03^{\circ} 48^{\prime} 00^{\prime \prime}$ & 91 & 29.6 \\
\hline & $\mathrm{R}$ & 08/06/98 & $42^{\circ} 35^{\prime} 07^{\prime \prime}$ & $03^{\circ} 37^{\prime} 03^{\prime \prime}$ & 175 & 37.0 \\
\hline & S & 08/06/98 & $42^{\circ} 48^{\prime} 13^{\prime \prime}$ & $03^{\circ} 28^{\prime} 92^{\prime \prime}$ & 96 & 35.2 \\
\hline & $\mathrm{T}$ & 08/06/98 & $43^{\circ} 01^{\prime} 05^{\prime \prime}$ & $03^{\circ} 19^{\prime} 98^{\prime \prime}$ & 66 & 20.4 \\
\hline & $\mathrm{U}$ & $16 / 06 / 98$ & $42^{\circ} 27^{\prime} 68^{\prime \prime}$ & $03^{\circ} 29^{\prime} 92^{\prime \prime}$ & 910 & 20.4 \\
\hline & V & $16 / 06 / 98$ & $42^{\circ} 29^{\prime} 61^{\prime \prime}$ & $03^{\circ} 09^{\prime} 55^{\prime \prime}$ & 35 & 1.9 \\
\hline
\end{tabular}

centres of these cores are on a $300 \mathrm{~mm}$ square. The penetration rate in the sediment is about $50 \mathrm{~mm} \mathrm{~s}^{-1}$. There were usually two successful drops per station. Three cores were analysed for the same biochemical parameters (except for carbohydrates, lipids, TPRT and APRT) and using the same protocols as described for the Pnoc cruises.
Seasonal changes along a depth gradient (35-920 m) were assessed off Banyuls-sur-Mer (BBLL cruises). Five stations (VTC, VL, INT1, INT2, AXE) were sampled during February 1997, August 1997, May 1998 and November-December 1998. Sediment samples were taken and analysed for biochemical parameters (total organic matter, organic carbon, 
nitrogen, carbohydrates, lipids, THAA and EHAA) as described for the HFF cruises. In addition, three other cores were subsampled to a depth of $5 \mathrm{~cm}$ using a $6.16 \mathrm{~cm}^{2}$ syringe. The collected sediment was fixed with $4 \%$ formalin in buffered seawater. Back at the laboratory, meiofauna was sieved on a $40 \mu \mathrm{m}$ mesh. The fraction retained on this mesh was diluted in ludox $1 / 2$ containing kaolin and centrifuged (5500 rpm, $15 \mathrm{~min}$ ). The supernatant was passed on a $40 \mu \mathrm{m}$ mesh and the fraction retained on this mesh was collected. This procedure was repeated three times resulting in an extraction efficiency close to 95\% (Keller, 1984, 1985). Meiofauna was then identified to the main taxa and counted under a dissecting stereo microscope. Nematode biomass was determined using the procedure described by DeBovée (1987). Macrofauna was sampled using a Fluscha grab (three $0.1 \mathrm{~m}^{2}$ replicates), sieved on a $1 \mathrm{~mm}$ mesh, fixed with $4 \%$ formalin in buffered seawater and stained with Rose Bengal. Back at the laboratory, these samples were sorted and identified to the species level. Macrofauna biomass (ash-free dry weight) was assessed by measuring weight loss after combustion $\left(450^{\circ} \mathrm{C}, 4 \mathrm{~h}\right)$.

Spatial distributions of both sedimentary organics and benthic fauna within the whole Gulf of Lion were assessed during June 1998 (Moogli II cruise). Nineteen stations (B-V) were sampled during this cruise, which took place on board of the R/V Suroît between 2 June and 28 June 1998. Sediment samples were taken and analysed (both for biochemical parameters and meiofauna) as described for the BBLL cruises except for THAA and EHAA that were quantified using a spectrofluorometrical rather than an HPLC assay. In addition, sediment granulometry was assessed (triplicates) on the fraction used for the biochemical assays using a Malvern Mastersizer 2000 laser microgranulometer. Macrofauna was sampled using a $0.25 \mathrm{~m}^{2}$ Usnel corer (unreplicated drop) and processed as described for the BBLL cruises.

Whenever possible, general patterns among POM biochemical characteristics and benthic fauna were assessed using principal component analysis (PCA). For BBLL, PCA included the following parameters: depth, organic content, organic carbon, nitrogen, $\mathrm{C} / \mathrm{N}$ ratio, carbohydrates, lipids, THAA, EHAA, EHAA/THAA ratio, abundance and biomass of macrofauna, abundance of meiofauna and nematod biomass. In addition, and because of the existence of different patterns of changes of both granulometrical/biochemical and faunistic parameters relative to depth, we decided to focus on the $0-175 \mathrm{~m}$ depth range to further assess the interactions between biochemical and faunistic parameters. This was achieved through two different PCA based on biochemical parameters (see above plus the distance to the coast and except $\mathrm{C} / \mathrm{N}$ and EHAA/THAA ratios) and either abundance or biomass of both meio- and macrofauna. These relationships were also assessed using simple linear regression models.

\section{Results}

\subsection{Quantitative and qualitative changes in THAA and EHAA}

Temporal changes in GSRs at the Pnoc site are presented in Fig. 2a. GSRs were between 0.26 (April 1995) and $470.55 \mathrm{~g} \mathrm{DW} \mathrm{m}^{-2} \mathrm{~d}^{-1}$ (19 December 1995). They showed important seasonal changes with an apparent period of 52 weeks (spectral analysis, data not shown). They tended to be maximal during fall and winter and minimal during spring and summer. Nitrogen contents of the collected material also showed important changes Fig. 2b. They were between $0.09 \%$ (13 October 1992) and 0.95\% (9 August 1994). Theyalso showed an apparent period of 52 weeks (data not shown) but tended to be maximal during spring and summer and minimal during fall and winter. GSR correlated negatively with all biochemical parameters. The best fits were obtained using semi-logarithmic models tTable 2). The steepest slopes were associated with APRT, EHAA and to a lesser extent with THAA and lipids. The flattest slopes were associated with carbohydrates and total organic matter. The slope corresponding to labile organic matter (LOM) as defined as the sum of total carbohydrates, proteins and lipids (Fichez, 1991) was similar to the one corresponding to organic carbon.

Temporal changes in the composition of THAA and EHAA at the Pnoc site are rather limited and appear to be mainly cued by the increase of degraded POM during sediment resuspension events (Medernach et al., 2001). Consequently, temporal changes in EHAA profiles are even

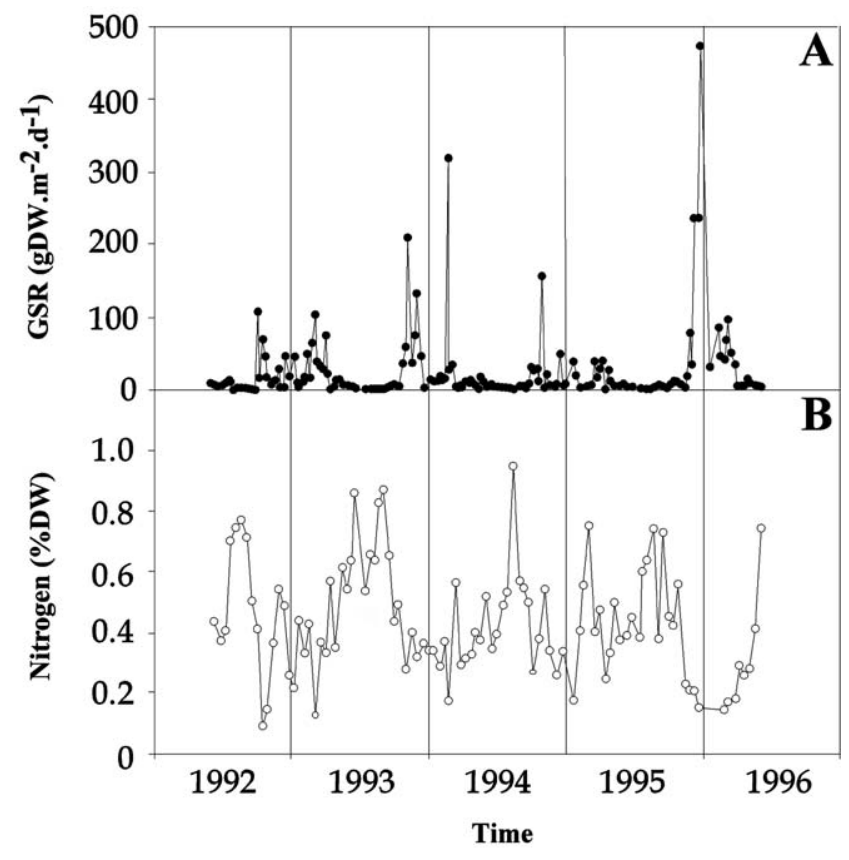

Fig. 2. Temporal changes in GSRs (A) and nitrogen contents (B) of the sediment trap material collected at the Pnoc site between June 1992 and 1996.

Fig. 2. Évolution temporelle des taux de sédimentation brute (A) et des contenus en azote $(\mathrm{B})$ des matériels recueillis dans les pièges à particules mouillés au site Pnoc entre juin 1992 et 1996. 
Table 2

Main characteristics of the simple linear regression models linking GSR and biochemical characteristics of the sediment trap material collected at the Pnoc site. All correlations are significant. $r^{2}$ : determination coefficient, $P$ : probability, $a$ : slope, $b$ : intercept, $N$ : number of observations. OM: organic matter, C: organic carbon, N: nitrogen, TPRT: total proteins, APRT: available proteins, THAA: total hydrolysable amino acids, EHAA: enzymatically hydrolysable amino acids, LOM: labile organic matter

Principales caractéristiques des modèles de régression linéaire simple reliant les taux de sédimentation brute et les principales caractéristiques biochimiques du matériel recueilli dans les pièges à particules au site Pnoc. Toutes les corrélations sont significatives. $\mathrm{r} 2$ coefficient de détermination, $\mathrm{P}$ : probabilité, a : pente, $\mathrm{b}$ : ordonnée à l'origine, $\mathrm{N}$ : nombre d'observations. OM : Matière organique, $\mathrm{C}$ : Carbone organique, $\mathrm{N}$ : Azote, TPRT : Protéines totales, APRT : Protéines disponibles, THAA : Acides aminés totaux, EHAA : Acides aminés hydrolyzables enzymatiquement à froid, LOM : Matière organique labile

\begin{tabular}{llllll}
\hline $\begin{array}{l}\text { Dependent } \\
\text { variables }\end{array}$ & $r^{2}$ & $P$ & $a$ & $b$ & $N$ \\
\hline OM & 0.424 & $<0.0001$ & -0.194 & 2.816 & 85 \\
$\mathrm{C}$ & 0.457 & $<0.0001$ & -0.223 & 1.578 & 85 \\
$\mathrm{~N}$ & 0.283 & $<0.0001$ & -0.255 & -0.422 & 85 \\
TPRT & 0.300 & $<0.0001$ & -0.307 & 3.015 & 85 \\
APRT & 0.531 & $<0.0001$ & -0.486 & 2.579 & 85 \\
Carbohydrates & 0.339 & $<0.0001$ & -0.174 & 3.792 & 85 \\
Lipids & 0.460 & $<0.0001$ & -0.333 & 2.065 & 85 \\
THAA & 0.599 & $<0.0001$ & -0.336 & 3.185 & 85 \\
EHAA & 0.539 & $<0.0001$ & -0.425 & 2.357 & 85 \\
LOM & 0.477 & $<0.0001$ & -0.223 & 4.325 & 85 \\
\hline
\end{tabular}

THAA
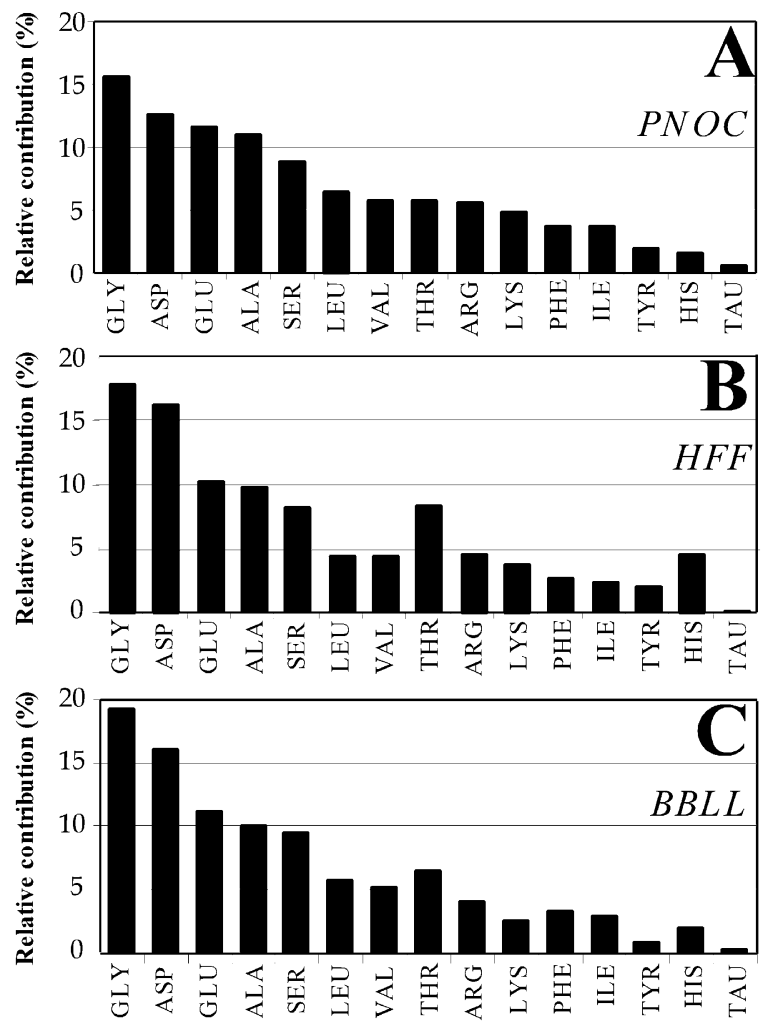

smaller. Average contributions of each individual amino acid to THAA and EHAA at the Pnoc site are presented in Fig. 3a,d These two profiles show strong similarities, the major differences being a higher contribution of glycine and lower contributions of both aspartic and glutamic acids for THAA. The average THAA profile of the sediment trap material collected at the Pnoc site shows great similarities with those of the sediments collected both during the HFF and the BBLL cruises Fig. 3b,c. This trend was also true for EHAA Fig. 3d-f, which is not surprising given the results observed at the Pnoc site (cf. above). Irrespective of geographical locations and seasons, it thus seems that the individual amino acid composition of both sedimenting and sedimented POM is rather constant in the Gulf of Lion.

EHAA/THAA ratios were between $13.9 \%$ and $65.8 \%$ at the Pnoc site, $26.2 \%$ and $33.7 \%$ at the HFF site, $16.3 \%$ and $32.1 \%$ at the BBLL sites and $16.9 \%$ and $29.6 \%$ at the Moogli II sites. The variances associated to these four surveys were highly different (Cochran $C$ tests, $P<0.0001$ ), which is not surprising given the heterogeneity in both spatial and temporal sampling strategies. Median values of EHAA/THAA ratios nevertheless significantly differed among surveys (Kruskal-Wallis ANOVA, $P<0.0001$ ) with a significantly higher value at the Pnoc site than during both the BBLL and the Moogli II cruises (Median Notch method).
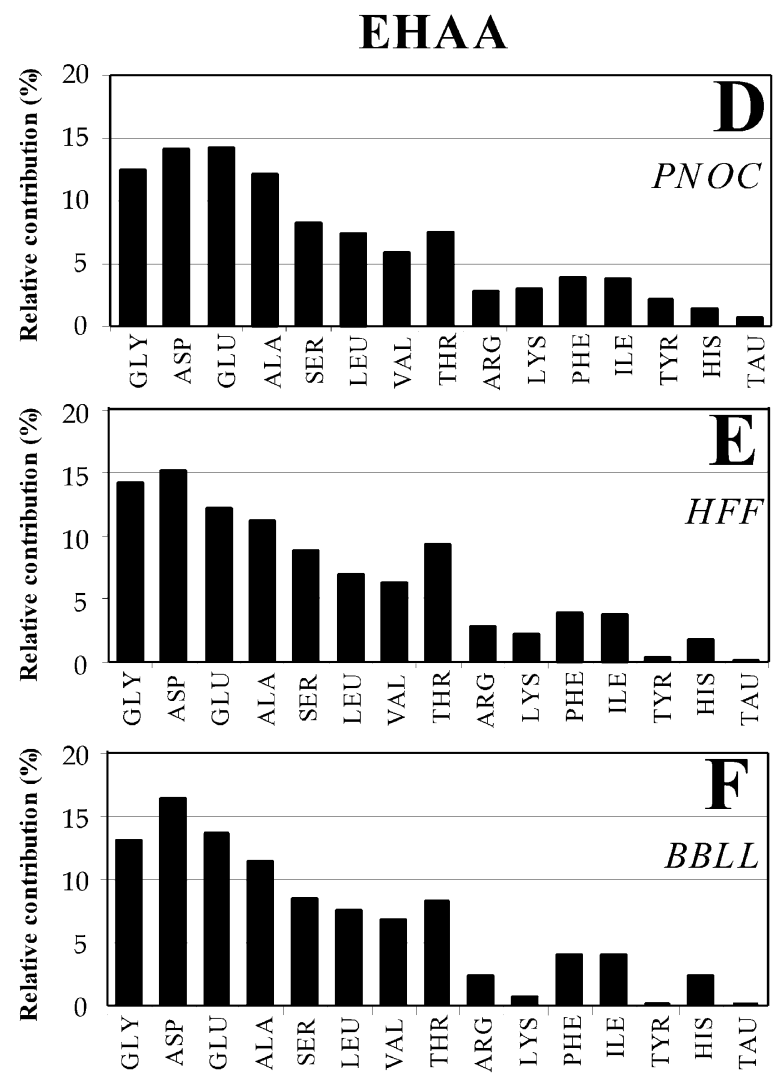

Fig. 3. Average THAA and EHAA spectra recorded during the Pnoc (A and D), HFF (B and E) and BBLL cruises (C and F).

Fig. 3. Spectres moyens en THAA et en EHAA enregistrés pendant les campagnes Pnoc (A et D), HFF (B et E) et BBLL (C et F). 


\subsection{Relationships between sedimentary organics and benthic fauna}

Spatio-temporal changes in sedimentary organic biochemical characteristics recorded during the BBLL cruises were highly depending on biochemical parameters Fig. 4. Temporal changes, however, often remained low when compared to spatial variations. Total organic matter, and carbohydrate contents tended to increase with depth (KruskalWallis ANOVAs, $P=0.022$ and 0.018, respectively) and showed higher median values at INT1 and AXE than at VTC and VL (Median Notch method). Nitrogen contents and EHAA/THAA ratios did not show any clear pattern relative to depth (Kruskal-Wallis ANOVA, $P=0.380$ and 0.639, respectively). This was also the case for lipids (KruskalWallis ANOVA, $P=0.780$ ) possibly due to an important temporal variability both at VTC and VL. At last THAA and EHAA tended to decrease with depth, although nonsignificantly (Kruskal Wallis ANOVAs, $P=0.068$ and 0.057 , respectively) with higher medians at VTC than at INT1, INT2 and AXE (Median Notch method).

Spatial and temporal changes in the main benthic faunal characteristics recorded during the BBLL cruises are presented in Fig. 5. Total meiofauna abundance and nematode biomass both decreased with depth (Kruskal-Wallis ANOVAs, $P=0.016$ and 0.011 , respectively) with a significantly higher median at VTC than at INT1 and AXE. Variances in both macrofauna abundance and biomass significantly differed among stations (Cochran $C$ test, $P=0.005$ and $P<0.001$, respectively). There was nevertheless a significant decrease of macrofauna abundance with depth (KruskalWallis ANOVA, $P=0.017$ ) with a significantly higher median at VTC than at INT1 and AXE (Median Notch method). This trend was also apparent for macrofauna biomass, although not statisticallysignificant (Kruskal-Wallis ANOVA, $P=0.085)$.

The projections of variables on the first plane of the PCA based on the physiographical, biochemical and faunal parameters recorded during the BBLL cruises are presented in Fig. 6. The first two components accounted for $49 \%$ and $19 \%$ of total variance, respectively. Component 1 opposed faunal characteristics together with THAA, EHAA and lipids on one side, versus depth, total organic matter and carbohydrates on the other side. Thus faunal parameters correlated positively with EHAA and to a lesser extent with THAA and lipids. This result was further supported by simple linear regression analysis Table 3. All meiofauna characteristics correlated positively with both THAA and EHAA, whereas all macrofauna characteristics (but biomass for THAA) correlated positively with lipids, THAA and EHAA. LOM did not correlate positively with any faunal parameter.

Examples of spatial distribution of the different biochemical parameters measured during the Moogli II cruise are presented in Fig. 7. All biochemical parameters showed the same distribution pattern. Concentrations of biochemical pa- rameters were always high (except at station D) at shallow depth (stations H, P, L, T and V) and lowest on the continental shelf edge and on the upper slope (stations C, F, G, J, K, N, O, $\mathrm{R}$ and $\mathrm{S}$ ). They then increased at greater depth (stations B, E, I and U). This resulted in a typical depth-related pattern of sedimentary organic matter concentrations Fig. 8a, which fits well with the abundance of fine particles within the sediment Fig. 8b. EHAA/THAA ratio Fig. 7 showed only limited changes over the whole studied area except for station D and to a lesser extent station N. Examples of the spatial distributions of faunal characteristics recorded during the Moogli II cruise are presented in Fig. 9. For both meiofauna abundance and nematode biomass, the highest values were recorded at shallow sites and the lowest ones at depth. There was no particular pattern of benthic faunal parameter associated to the edge of the continental shelf or the upper slope Fig. 8c. Macrofauna abundance and biomass also tended to be low at depth (stations E, I, N and U). However, high abundances were recorded either at very shallow depth (stations $\mathrm{H}$ and $\mathrm{V}$ ) or near the shelf break (stations $\mathrm{C}, \mathrm{G}, \mathrm{K}, \mathrm{O}$ and $\mathrm{S})$. Highest macrofauna biomasses were always recorded at shallow stations ( $\mathrm{T}$ and V). All faunal parameters (except macrofauna biomass) correlated negatively with depth Table 4.

The projections of variables on the first plane of the two PCAs including physiographical, biochemical parameters and both meio- and macrofauna abundances in the 0-175 m depth range (Moogli II) are presented in Fig. 10. In the PCA including meiofauna and macrofauna abundances Fig. 10a, the first two components accounted for $71 \%$ and $13 \%$ of total variance, respectively. The first component was characterised by the opposition between depth and distance to the coast on one side and all biochemical parameters on the other side. It was interpreted as reflecting quantitative changes in sedimentary organics. The second component separated biochemical parameters, with a gradient from lipids and EHAA to organic contents and carbohydrates. It was interpreted as indicative of changes in the lability of sedimentary organics. Macrofauna abundance seemed largely independent of all the other parameters. In contrast, the abundance of meiofauna was associated with biochemical parameters and most tightly with lipids and EHAA. A similar pattern was found for the PCA including nematode and macrofauna biomass Fig. 10b. These results were supported by simple regression analyses. When considering all stations with depth lower than $175 \mathrm{~m}$, meiofauna abundances indeed correlated positively with organic carbon, nitrogen, lipids, THAA and EHAA but not with organic contents and carbohydrates Table 5. The best fits were obtained with lipids and EHAA. The same pattern was true for nematode biomass even if this parameter also correlated positively with carbohydrates. Both meiofauna abundance and nematode biomass correlated positively with LOM. However, in both cases, the corresponding determination coefficients were lower than those obtained using THAA, lipids and EHAA as the inde- 

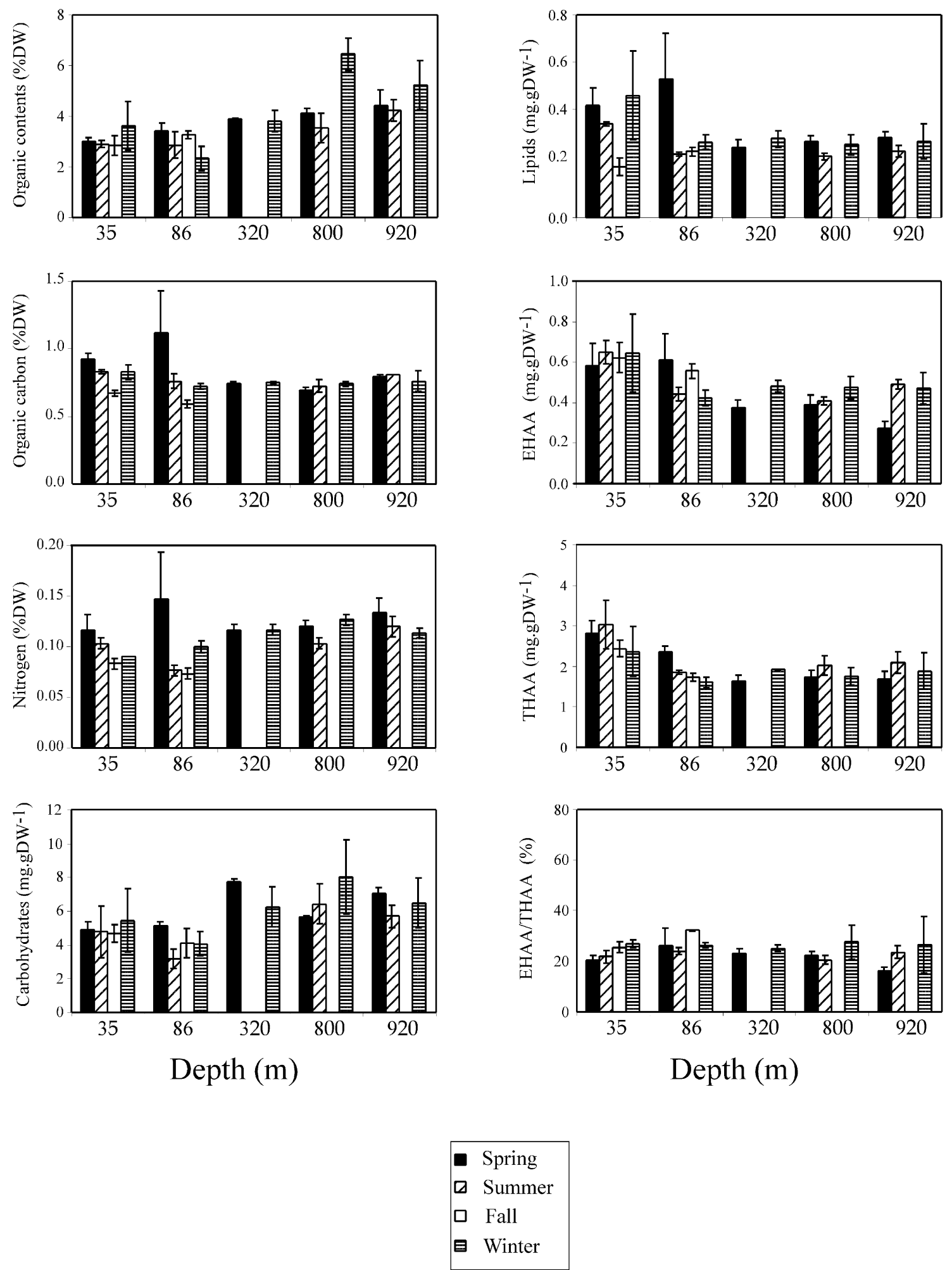

Fig. 4. Spatial and temporal changes in the main biochemical parameters recorded during the BBLL cruises.

Fig. 4. Variations spatio-temporelles des principaux paramètres biochimiques mesurés lors des campagnes BBLL. 

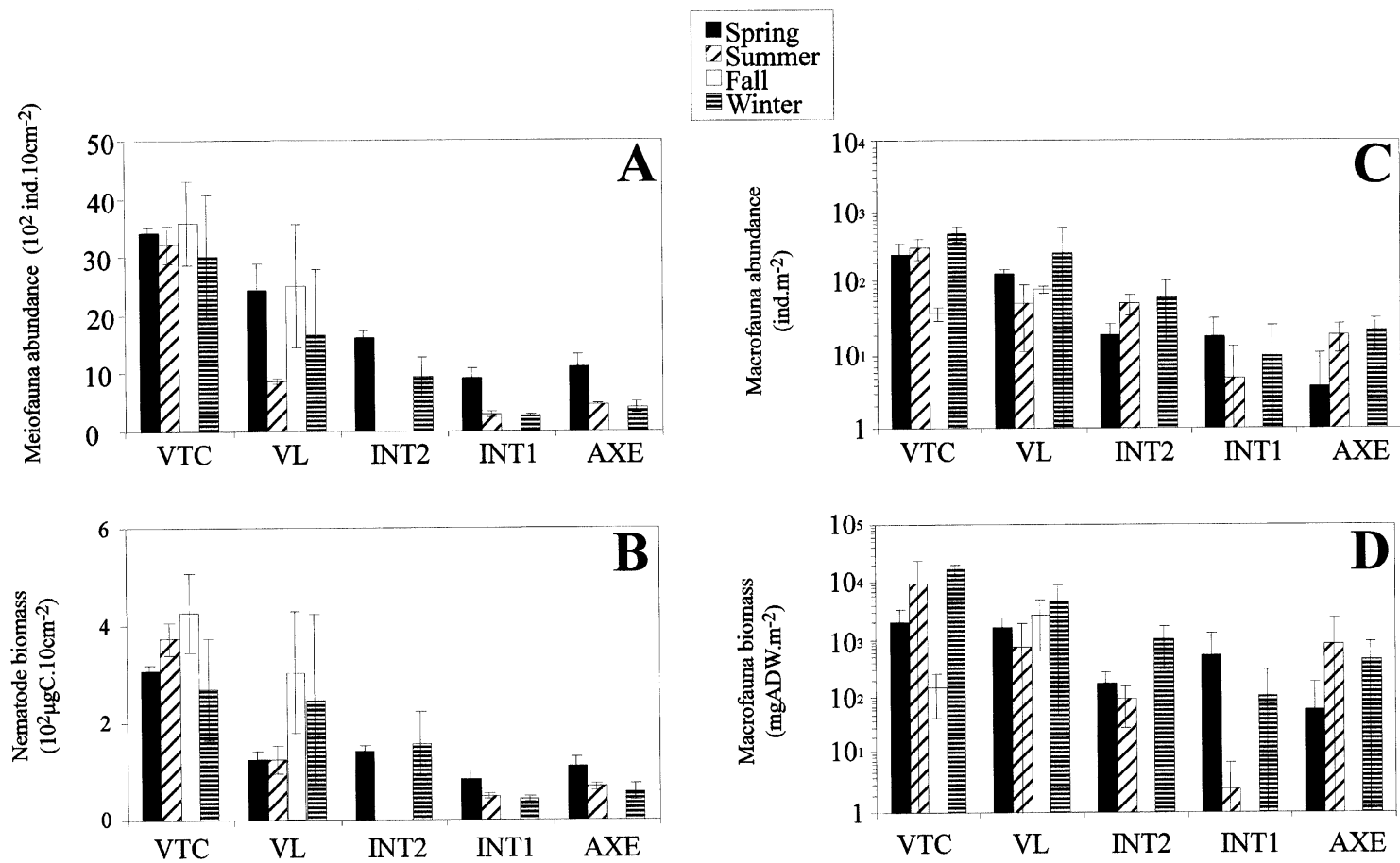

Fig. 5. Spatial and temporal changes in the main faunal parameters recorded during the BBLL cruises.

Fig. 5. Variations spatio-temporelles des principaux paramètres faunistiques mesurés lors des campagnes BBLL.

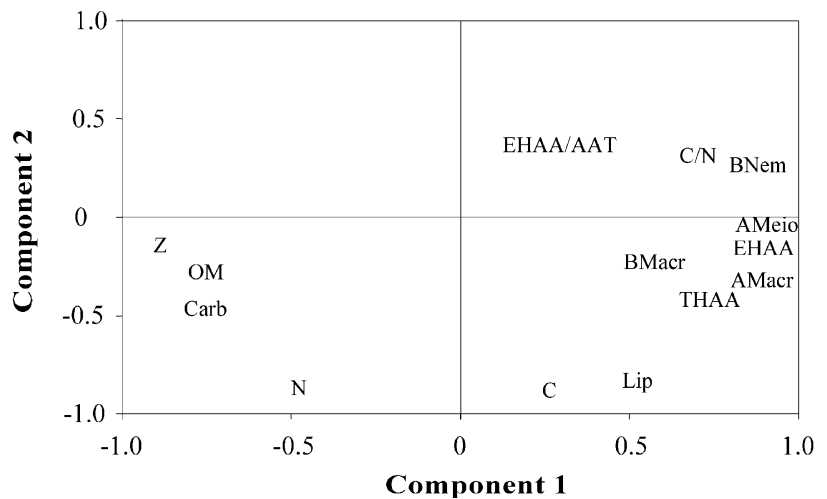

Fig. 6. Projection of the 14 considered variables (OM: organic matter, C: organic carbon, $\mathrm{N}$ : nitrogen, $\mathrm{C} / \mathrm{N}$, Carb: carbohydrates, Lip: lipids, THAA: total hydrolysable amino acids, EHAA: enzymatically hydrolysable amino acids, EHAA/THAA, Z: depth, AMacr: macrofauna abundance, BMacr: macrofauna biomass, AMeio: meiofauna abundance, and BNem: nematode biomass) in the first plane of the PCA based on the measurements carried out during the BBLL cruises.

Fig. 6. Projection des 14 variables considérées (OM : Matière organique, $\mathrm{C}$ : Carbone organique, $\mathrm{N}$ : Azote, C/N, Carb : Carbohydrates, Lip : Lipides, THAA : Acides aminés totaux, EHAA : Acides aminés disponibles, EHAA/THAA, Z : Profondeur, Amacr : Abondance de la macrofaune, Bmacr : Biomasse de la macrofaune, Ameio : Abondance de la meiofaune, et Bnem : Biomasse de la nématofaune) dans le premier plan de l'analyse en composantes principales basée sur les résultats obtenus pendant les campagnes BBLL.

pendent variable of the regression model. Within the same depth range, macrofauna abundance and biomass did not correlate significantly with any biochemical parameter.

\section{Discussion}

\subsection{Digestibility versus ability to meet nutritional requirements}

In order to be assimilated (i.e. incorporated into animal tissues), POM must first be ingested and then absorbed. Since only very small molecules can cross the gut wall, absorption is highly depending on the hydrolysing capacity of both gut surfactants and enzymes (Mayer et al., 1997). Once absorbed, the organic matter can either be metabolised quickly or assimilated. A key process in controlling the balance between these two fates is the ability of the absorbed POM to meet specific nutritional requirements. For example, this process constitutes the basis of the oxidation method which consists in determining essential amino acid requirements by monitoring the amount of radioactive $\mathrm{CO}_{2}$ produced after meals containing both a given amount of a labelled amino acid and varying concentrations of another, potentially limiting amino acid (Kim et al., 1983). More generally, the potential limitations by specific micronutrients appears more crucial in primary consumers because the biochemical composition of their food sources is much more variable than for secondary consumers (Phillips, 1984). If focussing on nitrogen, which is often considered as the limiting factor in benthic food chains, the nutritional value of POM may thus either be controlled by the rate at which proteins are hydrolysed within the gut, and/or by a lack in some specific essential amino acids that could limit assimilation.

The results of the present study show that average individual amino acid contributions to both THAA and EHAA 
Table 3

BBLL cruises. Main characteristics of the simple linear regression models linking biochemical and faunal parameters. Significant positive correlations $(P<0.05)$ are in bold. $r^{2}$ : determination coefficient, $P$ : probability, $a$ : slope, $b$ : intercept, $N$ : number of observations. OM: organic matter, C: organic carbon, $\mathrm{N}$ : nitrogen, TPRT: total proteins, APRT: available proteins, THAA: total hydrolysable amino acids, EHAA: enzymatically hydrolysable amino acids, LOM: labile organic matter

Campagnes BBLL. Principales caractéristiques des modèles de régression linéaire simple (16 couples de données) reliant les paramètres biochimiques et faunistiques. Les corrélations significativement $(\mathrm{p}<0.05)$ positives sont en gras. $\mathrm{r} 2:$ coefficient de détermination, $\mathrm{P}:$ probabilité, $\mathrm{a}:$ pente, $\mathrm{b}:$ ordonnée à l'origine, $\mathrm{N}$ : nombre d'observations. OM : Matière organique, $\mathrm{C}$ : Carbone organique, $\mathrm{N}$ : Azote, TPRT : Protéines totales, APRT : Protéines disponibles, THAA : Acides aminés totaux, EHAA : Acides aminés hydrolyzables enzymatiquement à froid, LOM : Matière organique labile

\begin{tabular}{|c|c|c|c|c|c|c|}
\hline $\begin{array}{l}\text { Independent } \\
\text { variables }\end{array}$ & $\begin{array}{l}\text { Regression } \\
\text { parameters }\end{array}$ & $\begin{array}{l}\text { Meiofauna } \\
\text { abundance }\end{array}$ & Nematode biomass & $\begin{array}{l}\text { Macrofauna } \\
\text { abundance }\end{array}$ & $\begin{array}{l}\text { Macrofauna } \\
\text { biomass }\end{array}$ & $N$ \\
\hline \multirow[t]{4}{*}{$\mathrm{MO}$} & $r^{2}$ & 0.373 & 0.313 & 0.200 & 0.080 & 16 \\
\hline & $a$ & -711 & -65 & -64 & -1243 & \\
\hline & $b$ & 4332 & 408 & 357 & 7254 & \\
\hline & $P$ & 0.012 & 0.024 & 0.082 & 0.289 & \\
\hline \multirow[t]{4}{*}{$\mathrm{C}$} & $r^{2}$ & 0.059 & 0.002 & 0.110 & 0.028 & 16 \\
\hline & $a$ & 2454 & -46 & 415 & 6342 & \\
\hline & $b$ & -242 & 201 & -208 & -2339 & \\
\hline & $P$ & 0.364 & 0.864 & 0.208 & 0.538 & \\
\hline \multirow[t]{4}{*}{$\mathrm{N}$} & $r^{2}$ & 0.090 & 0.259 & 0.055 & 0.094 & 16 \\
\hline & $a$ & -17455 & -2955 & -1691 & -67440 & \\
\hline & $b$ & 3565 & 486 & 299 & 9929 & \\
\hline & $P$ & 0.259 & 0.044 & 0.382 & 0.248 & \\
\hline \multirow[t]{4}{*}{ Lipids } & $r^{2}$ & 0.193 & 0.016 & 0.423 & 0.278 & 16 \\
\hline & $a$ & 5579 & 158 & 1023 & 25367 & \\
\hline & $b$ & -125 & 114 & -234 & -5552 & \\
\hline & $P$ & 0.089 & 0.644 & 0.006 & 0.035 & \\
\hline \multirow[t]{4}{*}{ Carbohydrates } & $r^{2}$ & 0.222 & 0.237 & 0.152 & 0.068 & 16 \\
\hline & $a$ & -416 & -43 & -43 & -872 & \\
\hline & $b$ & 3994 & 405 & 353 & 7476 & \\
\hline & $P$ & 0.065 & 0.055 & 0.135 & 0.328 & \\
\hline \multirow[t]{4}{*}{ THAA } & $r^{2}$ & 0.486 & 0.430 & 0.313 & 0.204 & 16 \\
\hline & $a$ & 1932 & 181 & 192 & 4733 & \\
\hline & $b$ & -2308 & -208 & -279 & -7141 & \\
\hline & $P$ & 0.003 & 0.006 & 0.024 & 0.079 & \\
\hline \multirow[t]{4}{*}{ EHAA } & $r^{2}$ & 0.246 & 0.539 & 0.372 & 0.314 & 16 \\
\hline & $a$ & 4267 & 8030 & 825 & 23136 & \\
\hline & $b$ & -283 & -2296 & -292 & -8823 & \\
\hline & $P$ & 0.035 & 0.001 & 0.012 & 0.024 & \\
\hline \multirow[t]{4}{*}{ LOM } & $r^{2}$ & 0.048 & 0.074 & 0.029 & 0.007 & 16 \\
\hline & $a$ & -201 & -25 & -19 & -288 & \\
\hline & $b$ & 3268 & 363 & 270 & 4891 & \\
\hline & $P$ & 0.416 & 0.309 & 0.525 & 0.760 & \\
\hline
\end{tabular}

spectra of sedimenting and sedimentary POM collected in various areas of the Gulf of Lions and at different seasons are very similar. This supports the constancy of THAA and EHHA spectra already reported by Medernach et al. (2001) during a 4 year time series regarding material collected within the sediment traps moored at the Pnoc site. These results suggest that irrespective of POM types, these are probably the same amino acids that are limiting secondary production of benthic primary consumers in the Gulf of Lion. Moreover, and because the relative proportions of each indi- vidual amino acid are nearly constant in this whole area, changes in the concentrations of those potentially limiting amino acids can be deduced from changes in the whole EHAA fraction. This suggests that the measurements of individual amino acids would only be of little help in determining sedimentary organic nutritional value in the Gulf of Lion.

Since EHAA are derived from a biomimetic approach (Mayer et al., 1995), the EHAA/THAA ratio can be considered as a crude index of sedimentary organic digestibility. At 

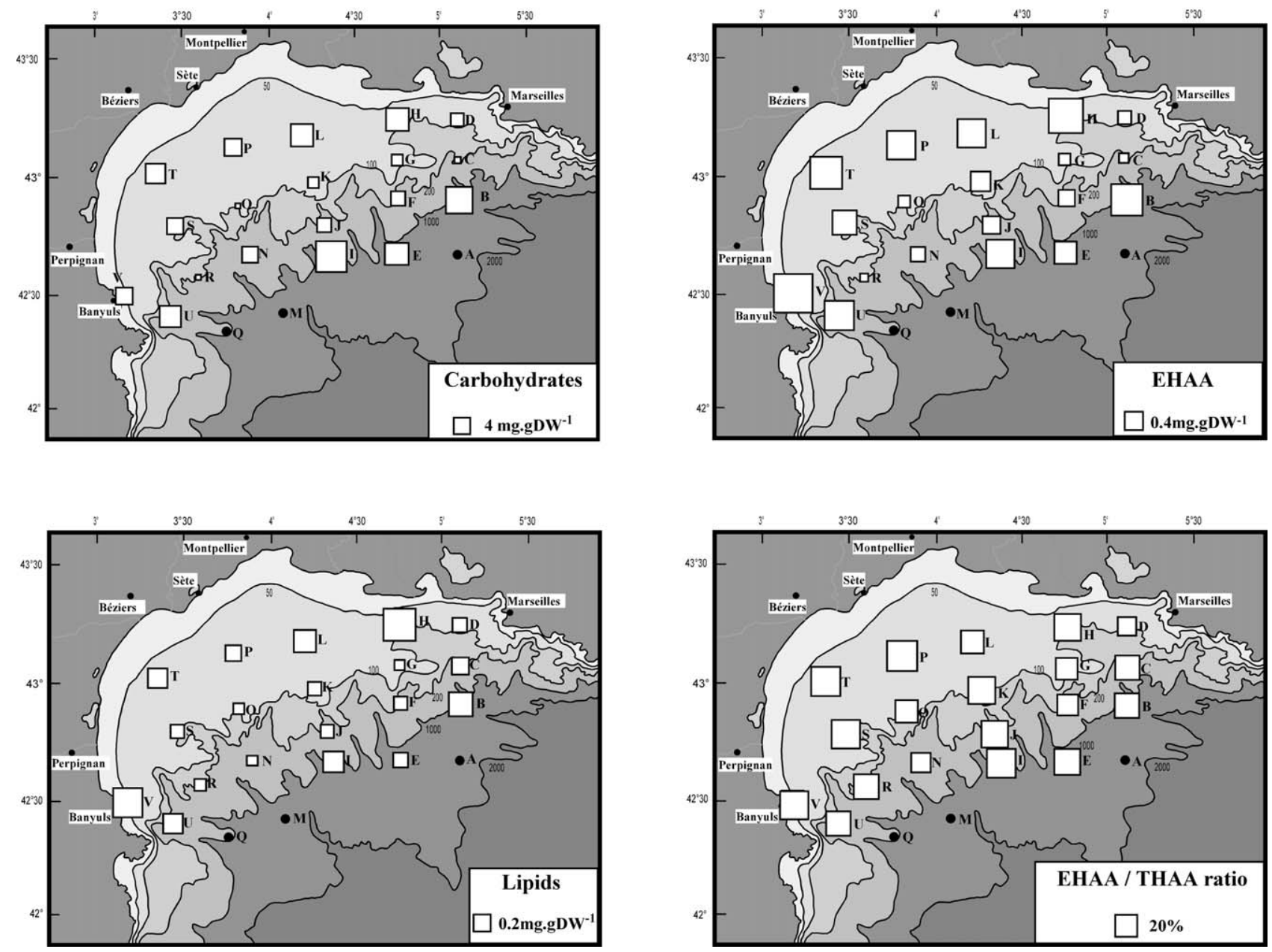

Fig. 7. Spatial distributions of the carbohydrate, lipid and EHAA concentrations, and of the EHAA/THAA ratios recorded during the Moogli II cruise. Fig. 7. Variations spatiales des concentrations en carbohydrates, lipides et EHAA ainsi que des rapports EHAA/THAA mesurés pendant la campagne Moogli II.

the Pnoc site, this index varied between $14 \%$ and $66 \%$. Furthermore, the existence of important temporal changes in POM digestibility at this site is documented by the direct absorption measurements (between $6 \%$ and $21 \%$ ) carried out by Charles et al. (1995) on sediment trap materials collected at different periods of the year. It is also supported by the wide range of APRT/TPRT ratios recorded at the same site over a 2-year period (Grémare et al., 1997). The variability of the EHAA/THAA ratio during the HFF cruises was much lower (i.e. between $26 \%$ and $34 \%$ ) which is not surprising given that this was a short-term survey conducted at a single site. However, both the BBLL and the MOOGLI II cruises also showed important variability in EHAA/THAA ratios, which were comprised between $16 \%$ and $32 \%$, and $17 \%$ and $30 \%$, respectively. The digestibility of POM nitrogenous compounds thus shows much more variability than amino acid composition, and especially in the EHAA pool (Medernach et al., 2001). Therefore, and based on results regarding nitrogenous compounds, digestibility appears more effective than the ability to meet specific nutritional requirements in controlling sedimentary organic nutritional value in the Gulf of Lion.

\subsection{Identifying a biochemical descriptor of sedimentary organic nutritional value}

There is still some controversy about the use of EHAA as a surrogate for proteins actually available to benthic primary consumers. One important potential problem is that hydrolysis is supposed to fully control absorption, whereas it is known that significant amount of the DOM resulting from this process do not cross the gut wall but are either used by bacteria in the hindgut (Plante et al., 1989) or released in the external medium through incomplete digestion (Jumars et al., 1989). Given such a potential artifact, it is essential to test the validity of this approach. Mayer et al. (1995) first compared the hydrolysis involving proteinase $\mathrm{K}$ with the one obtained using the gut fluid of the holothurian Parastichopus californicus. However, this first approach did not provide any insight on the fate of the organic matter, which is hydrolysed during digestion. Grémare et al. (1997) carried out another test of the biomimetic approach. These authors correlated APRT concentrations with the results of bioassays involving growth measurements in the deposit-feeding bivalve Abra ovata. Their results tended to support the use of APRT as an 

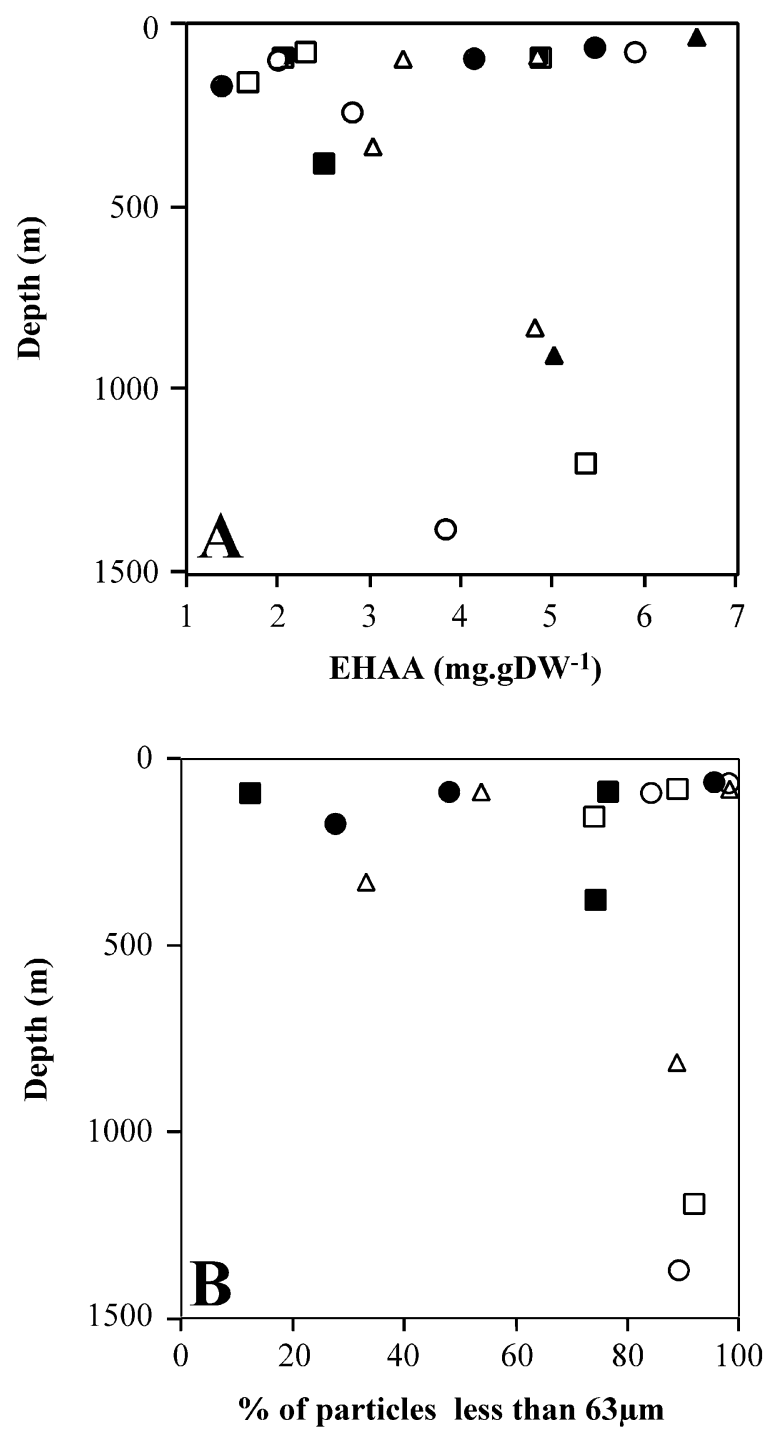

\begin{tabular}{|l|}
\hline Transect \\
\hline$\square$ BCD \\
O EFGH \\
$\triangle$ IJKL \\
$\square$ NOP \\
- RST \\
$\triangle$ UV \\
\hline
\end{tabular}

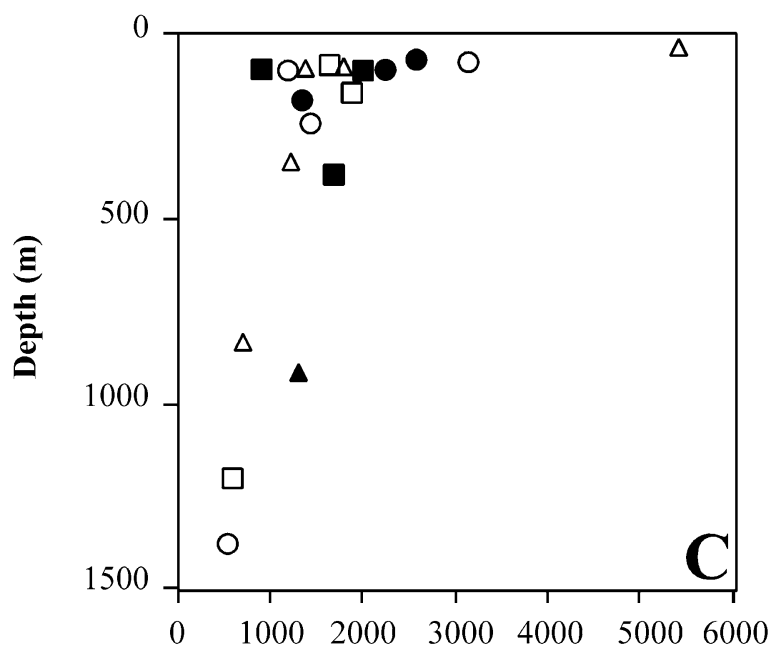

Meiofauna abundance (ind.10 $\mathrm{cm}^{-2}$ )

Fig. 8. Relationships between EHAA concentration (A), percentage of sediment particles less than $63 \mu \mathrm{m}$ in size (B), and total meiofauna abundance (C) and water depth at the stations sampled during the Moogli II cruise.

Fig. 8. Relations liant la concentration en EHAA (A), la proportion de particules dont la taille est inférieure à $63 \mu \mathrm{m}$ (B) et l'abondance de la meiofaune (C) avec la profondeur aux stations échantillonnées pendant la campagne Moogli II. 

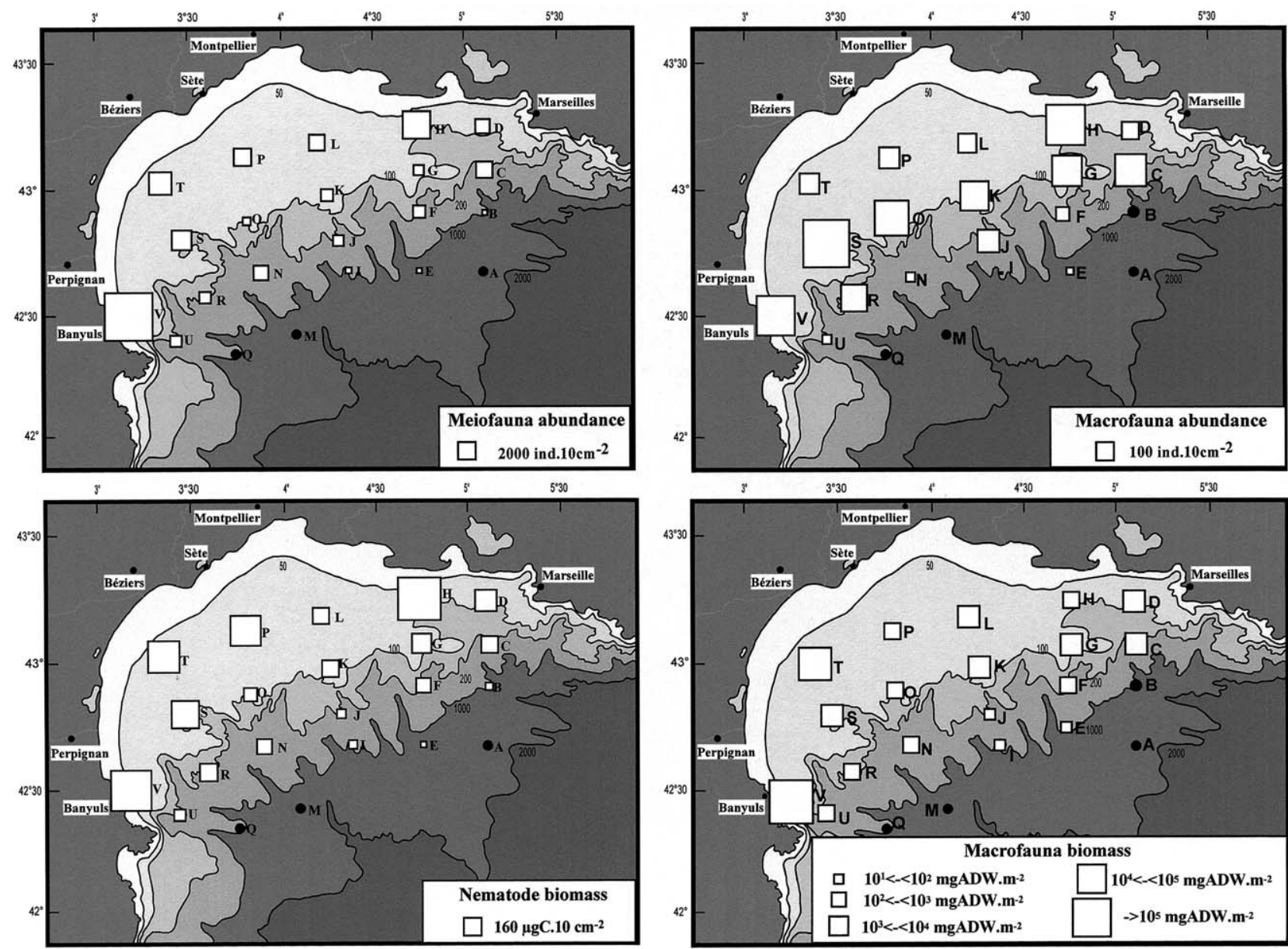

Fig. 9. Spatial distributions of meiofauna abundance, nematode biomass, macrofauna abundance and macrofauna biomass recorded during the Moogli II cruise. Fig. 9. Variations spatiales de l'abondance de la meiofaune, de la biomasse de la nematofaune, ainsi que de l'abondance et de la biomasse de la macrofaune telles que mesurées pendant la campagne Moogli II.

Table 4

Moogli II cruise. Main characteristics of the semi-logarithmic regression models linking faunal parameters and depth. Significant $(P<0.05)$ correlations are in bold. $r^{2}$ : determination coefficient, $P$ : probability, $a$ : slope, $b$ : intercept, $N$ : number of observations

Campagne Moogli II. Principales caractéristiques des modèles de régression semi-logarithmique liant les faunistiques et la profondeur. $\mathrm{r} 2$ : coefficient de détermination, $\mathrm{P}$ : probabilité, $\mathrm{a}$ : pente, $\mathrm{b}$ : ordonnée à l'origine, $\mathrm{N}$ : nombre d'observations

\begin{tabular}{llllll}
\hline Dependent variables & $r^{2}$ & $P$ & $a$ & $b$ & $N$ \\
\hline Meiofauna abundance & 0.453 & 0.002 & -682.4 & 5277.5 & 19 \\
Nematode biomass & 0.608 & $<0.001$ & -65.2 & 506.6 & 19 \\
Macrofauna abundance & 0.547 & $<0.001$ & -49.3 & 381.2 & 18 \\
Macrofauna biomass & 0.187 & 0.073 & -10868.8 & 63648.0 & 18
\end{tabular}

index of POM nutritional value. However, food quality is not an inherent property of the sediment itself but rather results from an interaction between sediment and benthic organisms (Mayer et al., 1995). Because digestive capacities differ among benthic invertebrates, generalisation on the validation of the biomimetic approach carried out on single benthic species thus remains questionable (Mayer et al., 1995). A complementary way of testing the biomimetic approach thus consists of comparing the ability of several biochemical parameters to describe quantitative changes in benthic fauna (Medernach et al., 2001). This approach was used during the present survey based on the results collected during the BBLL and Moogli II cruises. In both cases, EHAA correlated best with quantitative changes in both meio and macrofauna abundance and biomass. This was also evident from the PCA results of the BBLL and the Moogli II data sets that allowed to link faunal parameters with both lipids and EHAA. The same approach allowed to identify a putative gradient of the effectiveness of different nutritional value indicators moving from lipids and EHAA (best descriptors) towards carbohydrates and total organic matter (worst descriptors). In this sense, our results thus tend to support the use of EHAA as an index of sedimentary organic nutritional value. They thus support the biomimetic approach proposed by Mayer et al. (1986, 1995).

The shape of the negative relationships between GSRs and biochemical characteristics recorded at the Pnoc site suggests that the material collected within the sediment traps results from the mixing of two sources: one composed of fresh POM sedimenting directly from the water column and the other composed of more degraded resuspended POM 

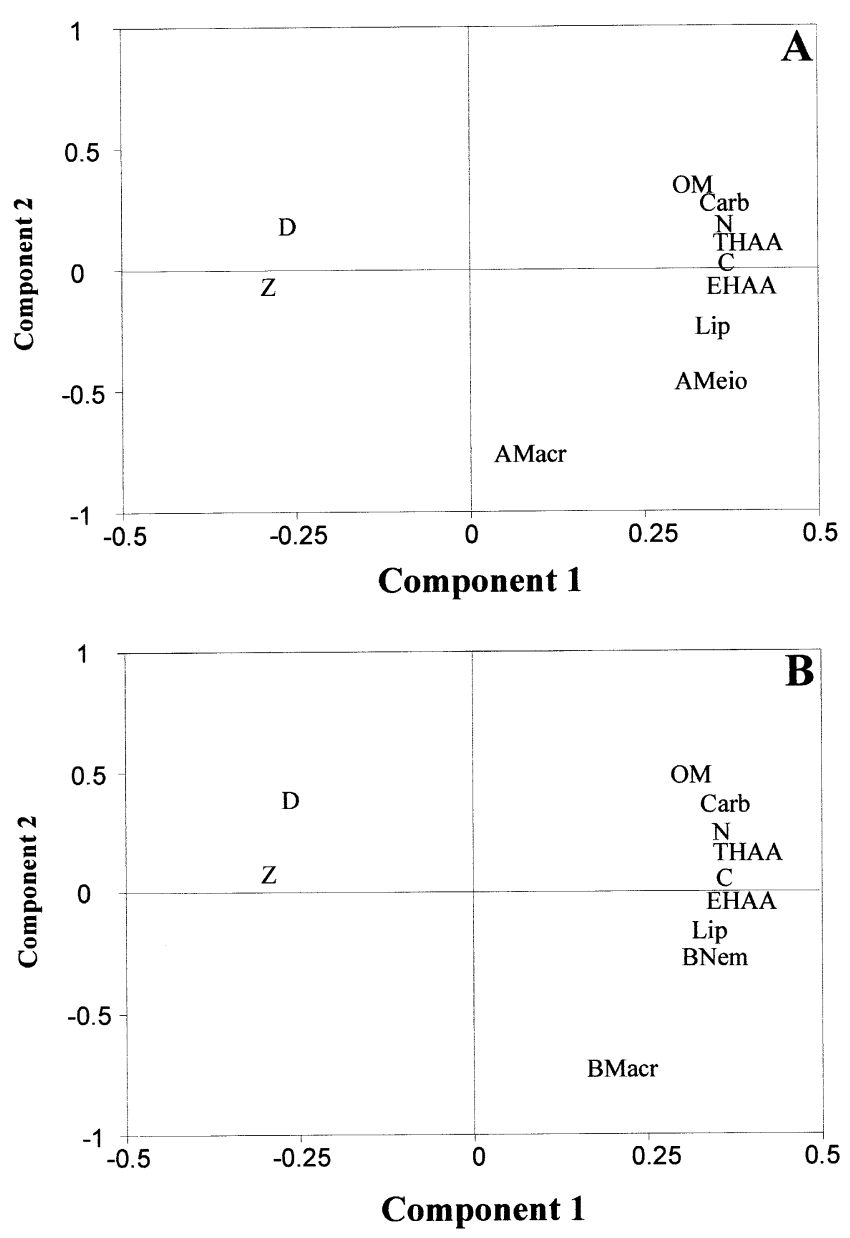

Fig. 10. Projections of the variables on the first two planes of the two PCAs based on both physiographical, biochemical and faunal parameters measured at the stations sampled during the Moogli II cruise and whose depth are less than $175 \mathrm{~m}$. The first PCA (A) is based on: $Z$ (depth), $D$ (distance to the coast), C (organic carbon), N (nitrogen), OM (organic contents), Carb (carbohydrates), Lip (lipids), THAA (total hydrolysable amino acids), EHAA (enzymatically hydrolysable amino acids), AMeio: abundance of meiofauna, and AMacr (abundance of macrofauna). The last two variables are replaced by BNem (biomass of nematodes) and BMacr (biomass of macrofauna) within the second PCA (B).

Fig. 10. Projections des variables sur les deux premiers plans principaux des deux ACP basées sur les paramètres physiographiques, biochimiques et faunistiques mesurées aux stations échantillonnées durant la campagne Moogli II et dont les profondeurs sont inférieures à 175 mètres. La première ACP (A) est basée sur: Z (profondeur), D (distance à la côte), C (carbone organique), N (azote), OM (contenus organiques), Carb (carbohydrates), Lip (lipides), THAA (acides aminés totaux), EHAA (acides aminés disponibles), AMeio:abondance de la meiofaune, et AMacr (abondance de la macrofaune). Ces deux dernières variables sont remplacées par BNem (biomasse de la nématofaune) et BMacr (biomasse de la macrofaune) dans la seconde $\mathrm{ACP}(\mathrm{B})$.

(Grémare et al., 1997, 1998). It is then possible to use the slopes of these regression models as indices of the ability of these biochemical characteristics to describe a more or less refractory fraction of sedimentary organics. More specifically, the steepest slopes will be obtained for the biochemical parameters associated with the most labile fraction of POM (since the differences between concentrations in the material sedimenting directly from the water column and in the resus- pended material are maximal for those parameters). Based on this approach, our results show that APRT, EHAA, and lipids are associated to the most labile fraction of POM whereas carbohydrates and organic contents are associated to the most refractory ones. Thus, the two suspected best descriptors (i.e. lipids and EHAA) of sedimentary organic nutritional value were both associated to the most labile fractions of sedimentary organics, which were considered during the present study. In the future, it may thus prove interesting to test other biomimetic approaches based on even softer hydrolysis procedures.

Moreover, carbohydrates, TPRT and lipids are associated to very different levels of POM lability. Together with its poor ability (Moogli II cruise) or even its inability (BBLL cruises) to describe changes in quantitative characteristics of benthic fauna, this should preclude the use of LOM as a proxy of sedimentary organic nutritional value.

\subsection{Consequences on the modelling of benthic trophic network in the Gulf of Lion}

Current models of benthic trophic networks and benthic fluxes are based on global descriptors of sedimentary organics such as organic carbon (Chardy, 1987) or nitrogen (Dadou et al., 2001). Attempts to take into account POM bioavailability in these kinds of models are yet preliminary. For example, the early diagenesis submodel used by Dadou et al. (2001) distinguishes between three types of organic matter: namely LOM, intermediate-reactive organic matter and refractory organic matter, which is supposed to represent $0.1 \%$ of sediment dry weight. A major difficulty consists in defining both reliable and simple enough protocols to quantify those fractions in order to both feed and test diagenetic models. The same problem also hands when considering POM bioavailability in benthic trophic network models.

The potential weaknesses of benthic trophic network models regarding POM bioavailability have already been discussed in Grémare et al. (1997). These authors underlined that, due to the heterogeneity in the composition of their potential food sources, absorption rates of benthic primary consumers should change as a function of the consumed food. They also recommended that secondary production should be computed based on a control function linking the amount of absorbed matter and growth, and suggested that this function could be based on APRT. Results from the present study suggest that such a function could also be used to directly assess benthic standing stocks based on sediment concentrations in EHAA and lipids.

However, it should be stressed that the results of the Moogli II cruise clearly show that this approach should not be carried out on the whole Gulf of Lion, but restricted to the continental shelf (i.e. depth less than $175 \mathrm{~m}$ ) and to the lower continental slope and the abyssal plain (i.e. depth greater than $900 \mathrm{~m}$ ). Indeed, the existence of a negative correlation between sedimentary organic biochemical characteristics and benthic standing stocks on the upper continental slope 
Table 5

Main characteristics of the linear regression models linking biochemical and faunal parameters recorded during the Moogli II cruise within the $0-175 \mathrm{~m}$ depth range. Significant positive correlations $(P<0.05)$ are in bold. $r^{2}$ : determination coefficient, $P$ : probability, $a$ : slope, $b$ : intercept, $N$ : number of data

Principales caractéristiques des modèles de régression linéaire simple reliant les paramètres biochimiques et faunistiques enregistrés pendant la campagne Moogli II entre 0 et $175 \mathrm{~m}$ de profondeur. Les corrélations significativement ( $<$ < 0.05$)$ positives sont en gras. $\mathrm{r} 2$ : coefficient de détermination, P : probabilité, $\mathrm{a}$ : pente, $\mathrm{b}$ : ordonnée à l'origine, $\mathrm{N}$ : nombre de données

\begin{tabular}{|c|c|c|c|c|c|c|}
\hline $\begin{array}{l}\text { Independent } \\
\text { variables }\end{array}$ & $\begin{array}{l}\text { Regression } \\
\text { parameters }\end{array}$ & $\begin{array}{l}\text { Meiofauna } \\
\text { abundance }\end{array}$ & Nematode biomass & $\begin{array}{l}\text { Macrofauna } \\
\text { abundance }\end{array}$ & $\begin{array}{l}\text { Macrofauna } \\
\text { biomass }\end{array}$ & $N$ \\
\hline \multirow[t]{4}{*}{$\mathrm{OM}$} & $r^{2}$ & 0.121 & 0.278 & 0.007 & 0.002 & 12 \\
\hline & $P$ & 0.268 & 0.078 & 0.799 & 0.892 & \\
\hline & $a$ & 437.9 & 46.6 & -4.440 & 1422.667 & \\
\hline & $b$ & 865.1 & 79.3 & 176.950 & 8163.261 & \\
\hline \multirow[t]{4}{*}{$\mathrm{C}$} & $r^{2}$ & 0.482 & 0.593 & 0.000 & 0.157 & 12 \\
\hline & $P$ & 0.012 & 0.003 & 0.938 & 0.202 & \\
\hline & $a$ & 3365.7 & 262.2 & 5.201 & 49554.350 & \\
\hline & $b$ & 152.0 & 59.4 & 160.970 & -16648.700 & \\
\hline \multirow[t]{4}{*}{$\mathrm{N}$} & $r^{2}$ & 0.353 & 0.521 & 0.006 & 0.080 & 12 \\
\hline & $P$ & 0.042 & 0.008 & 0.813 & 0.373 & \\
\hline & $a$ & 27011.5 & 2301.7 & -148.718 & 331341.333 & \\
\hline & $b$ & 222.0 & 51.0 & 174.410 & -10977.200 & \\
\hline \multirow[t]{4}{*}{ Lipids } & $r^{2}$ & 0.661 & 0.605 & 0.044 & 0.283 & 12 \\
\hline & $P$ & 0.001 & 0.003 & 0.514 & 0.075 & \\
\hline & $a$ & 11728.7 & 787.9 & 129.089 & 197819.930 & \\
\hline & $b$ & -343.3 & 47.2 & 136.967 & -29210.200 & \\
\hline \multirow[t]{4}{*}{ Carbohydrates } & $r^{2}$ & 0.263 & 0.452 & 0.004 & 0.033 & 12 \\
\hline & $P$ & 0.088 & 0.016 & 0.840 & 0.573 & \\
\hline & $a$ & 397.1 & 36.5 & -2.171 & 3617.062 & \\
\hline & $b$ & 737.5 & 85.7 & 171.518 & -310.359 & \\
\hline \multirow[t]{4}{*}{ THAA } & $r^{2}$ & 0.423 & 0.516 & 0.000 & 0.143 & 12 \\
\hline & $P$ & 0.022 & 0.008 & 0.949 & 0.226 & \\
\hline & $a$ & 986.9 & 76.5 & 1.342 & 14776.700 & \\
\hline & $b$ & 166.6 & 61.4 & 161.354 & -16922.400 & \\
\hline \multirow[t]{4}{*}{ EHAA } & $r^{2}$ & 0.612 & 0.676 & 0.023 & 0.291 & 12 \\
\hline & $P$ & 0.003 & 0.001 & 0.639 & 0.070 & \\
\hline & $a$ & 4068.8 & 300.3 & 33.699 & 72354.420 & \\
\hline & $b$ & 178.0 & 69.3 & 147.976 & -22189.300 & \\
\hline \multirow[t]{4}{*}{ LOM } & $r^{2}$ & 0.405 & 0.496 & 0.003 & 0.050 & 12 \\
\hline & $P$ & 0.026 & 0.011 & 0.856 & 0.484 & \\
\hline & $a$ & 0.001 & 0.020 & -0.002 & $1.57 \times 10^{-5}$ & \\
\hline & $b$ & 5.740 & 1.423 & 8.307 & 7.708 & \\
\hline
\end{tabular}

(i.e. the $175-900 \mathrm{~m}$ depth range) suggests that other factors than organic matter availability might control benthic fauna in this zone.

\section{Acknowledgements}

Laurence Medernach was supported by a doctoral grant of the French Ministère de la Recherche et de la Technologie. Besides the Pnec, parts of this work were funded through the EEC projects Metromed (complementary study at the Pnoc site) and Mater (HFF and continental slope stations of
BBLL). We would like to thank the two anonymous referees for their constructive comments on the manuscript.

\section{References}

Alkemade, R., Wielemaker, A., de Jong, S.A., Sandee, A.J.J., 1992. Experimental evidence for the role of bioturbation by the marine nematode Diplolaimella dievengatensis in stimulating the mineralization of Spartina anglica detritus. Mar. Ecol. Prog. Ser. 90, 149-155.

Barnes, H., Blackstock, J., 1973. Estimation of lipids in marine animals and tissues: detailed investigation of the sulphophosphovanillin method for "total” lipids. J. Exp. Mar. Biol. Ecol. 12, 103-118. 
Bianchi, T.S., 1988. Feeding ecology of subsurface deposit-feeder Leitoscoloplos fragilis Verril. 1. Mechanisms affecting particle availability on an intertidal sandflat. J. Exp. Mar. Biol. Ecol. 115, 79-97.

Blair, N.E., Levin, L.A., DeMaster, D.J., Plaia, G., 1996. The short-term fate of fresh algal carbon in continental slopes sediments. Limnol. Oceanogr. 41, 1208-1219.

Buscail, R., Germain, C., 1997. Present-day organic matter sedimentation on the NW Mediterranean margin: importance of shelf export. Limnol. Oceanogr. 42, 217-229.

Cammen, L.M., 1980. Ingestion rate: an empirical model for aquatic deposit-feeders and detritivores. Oecologia 44, 303-310.

Chardy, P., 1987. Modèle de simulation du système benthique des sédiments grossiers du golfe normand-breton (Manche). Oceanol. Acta 10, 421434.

Charles, F., 1994. Étude expérimentale du niveau d'utilisation de matériel détritique d'origines différentes par le bivalve dépositivore Abra ovata. Thèse Univ. Pierre et Marie Curie. pp. 291.

Charles, F., Amouroux, J.M., Grémare, A., Baudart, J., 1995. A bioassay approach to temporal variation in the nutritional value of sediment trap material. J. Exp. Mar. Biol. Ecol. 191, 65-81.

Dadou, I., Lamy, F., Rabouille, C., Ruiz-Pino, D., ersen, V., Bianchi, M., Garçon, V., 2001. An integrated biological pump model from the euphotic zone to the sediment: a 1-D application in the Northeast tropical Atlantic. Deep-Sea Res. II 48, 2345-2381.

DeBovée, F., 1987. Biomasse et équivalents énergétiques des nématodes libres marins. Cah. Biol. Mar. 28, 367-372.

DeBovée, F., Guidi, L.D., Soyer, J., 1990. Quantitative distribution of deep-sea meiobenthos in the northwestern Mediterranean (Gulf of Lions). Cont. Shelf Res. 10, 1123-1145.

Dobbs, F.C., Scholly, T.A., 1986. Sediment processing and selective feeding by Pectinaria koreni (Polychaeta: Pectinariidae). Mar. Ecol. Prog. Ser. $29,165-176$.

Dubois, M., Gilles, K.A., Hamilton, J.K., Rebers, P.A., Smith, F., 1956. Colorimetric method for determination of sugars and related substances. Anal. Chem. 28, 350-356.

Durrieu de Madron, X., Nyffeler, F., Godet, C.H., 1990. Hydrographic structure and nepheloid spatial distribution in the Gulf of Lions continental margin. Cont. Shelf Res. 10, 915-929.

Fichez, R., 1991. Suspended particulate organic matter in a Mediterranean submarine benthic cave. Mar. Biol. 108, 167-174.

Findlay, R.H., Trexler, M.B., White, D.C., 1990. Response of benthic microbial community to biotic disturbance. Mar. Ecol. Prog. Ser. 62, 135-148.

Graf, G., 1992. Benthic-pelagic coupling: a benthic view. Oceanogr. Mar. Biol. Ann. Rev. 30, 149-190.

Grémare, A., 1988. Feeding, tube building and particle size selection in the terebellid polychaete Eupolymnia nebulosa. Mar. Biol. 97, 243-252.

Grémare, A., Amouroux, J.M., Charles, F., Medernach, L., Jordana, E., Nozais, C., Vétion, G., Colomines, J.C., 1998. Temporal changes in the biochemical composition of the particulate organic matter sedimentation in the Bay of Banyuls-sur-Mer. Oceanol. Acta 21, 783-792.

Grémare, A., Amouroux, J.M., Charles, F., Dinet, A., Riaux-Gobin, C., Baudart, J., Medernach, L., Bodiou, J.Y., Vétion, G., Colomines, J.C., Albert, P., 1997. Temporal changes in the biochemical composition and nutritional value of the particulate organic matter available to surface deposit-feeders: a 2-year study. Mar. Ecol. Prog. Ser. 150, 195-206.

Jumars, P.A., Self, R.F.L., Nowell, A.R.M., 1982. Mechanics of particle selection by tentaculate deposit-feeders. J. Exp. Mar. Biol. Ecol. 64, 47-70.

Jumars, P.A., Penry, D.L., Baross, J.L., Perry, M.J., Frost, B.W., 1989. Closing the microbial loop: dissolved carbon pathway to heterotrophic bacteria from incomplete ingestion, digestion and absorption in animals. Deep-Sea Res. 364, 483-495.

Keller, M., 1984. Influence du rejet en mer de l'égout de Marseille sur les peuplements du meiobenthos. Thèse $3^{\mathrm{e}}$ cycle Univ. Marseille. pp. 131.

Keller, M., 1985. Distribution quantitative de la méiofaune dans l'aire d'épandage de l'égout de Marseille. Mar. Biol. 89, 293-302.
Kim, K.I., Mac Millan, I., Bayley, H.S., 1983. Oxidation of an indicator amino acid by young pigs receiving diets with varying levels of lysine or threonine, and an assessment of amino acid requirements. Br. J. Nutr. 50, 391-399.

Levin, L.A., Blair, N.E., DeMaster, D., Plaia, G., Fornes, W., Martin, C., Thomas, C., 1997. Rapid subduction of organic matter by maldanid polychaete on the North Carolina slope. J. Mar. Res. 55, 595-611.

Lowry, O.H., Rosebrough, N.J., Farr, A.L., Randall, R.J., 1951. Protein measurement with the Folin phenol reagent. J. Biol. Chem. 193, 265275.

Luckenback, M.W., 1986. Sediment stability around animal tubes: the roles of hydrodynamic processes and biotic activities. Limnol. Oceanogr. 31, 779-787.

Marsh, A.G., Tenore, K.R., 1990. The role of nutrition in regulating the population dynamics of opportunistic surface deposit-feeders in a mesohalyne community. Limnol. Oceanogr. 35, 710-724.

Mayer, L.M., Schick, L.L., Setchell, F.W., 1986. Measurement of protein in nearshore marine sediments. Mar. Ecol. Prog. Ser. 30, 159-165.

Mayer, L.M., Schick, L.L., Sawyer, T., Plante, C.J., Jumars, P.A., Self, R.F.L., 1995. Biovailable amino acids in sediments: a biomimetic, kinetics-based approach. Limnol. Oceanogr. 40, 511-520.

Mayer, L.M., Schick, L.L., Self, R.F.L., Jumars, P.A., Findlay, R.H., Chen, Z., Sampson, S., 1997. Digestive environments of benthic macroinvertebrate guts: enzymes, surfactants and dissolved organic matter. J. Mar. Res. 55, 785-812.

Medernach, L.M., Grémare, A., Amouroux, J.M., Colomines, J.C., Vétion, G., 2001. Temporal changes in the amino acid contents of particulate organic matter sedimenting in the Bay of Banyuls-sur-Mer (northwestern Mediterranean). Mar. Ecol. Prog. Ser. 214, 55-65.

Millot, C., 1990. The Gulf of Lion's hydrodynamics. Cont. Shelf Res. 10, 885-894.

Monaco, A., Durrieu de Madron, X., Radacovitch, O., Heussner, S., Carbonne, J., 1999. Origin and variability of downward biogeochemical fluxes on the Rhône continental margin (NW Mediterranean). Deep-Sea Res. 46, 1483-1511.

Moriarty, D.J.W., Pollard, P.C., Hunt, W.G., Moriarty, C.M., Wassenberg, T.J., 1985. Productivity of bacteria and microalgae and the effect of grazing by holothurians in sediments on a coral reef flat. Mar. Biol. 85, 293-300.

Phillips, N.W., 1984. Roles of different microbes and substrates as potential suppliers of specific essential nutrients to marine detritivores. Bull. Mar. Sci. 12, 33-47.

Plante, C.J., Jumars, P.A., 1992. The microbial environment of marine deposit-feeder guts characterized via microelectrodes. Microb. Ecol. 23, 257-277.

Plante, C.J., Shriver, A.G., 1998. Differential lysis of sedimentary bacteria by Arenicola marina L.: examination of cell wall structure and exopolymeric capsules as correlates. J. Exp. Mar. Biol. Ecol. 229, 35-52.

Plante, C.J., Jumars, P.A., Barros, J.A., 1989. Rapid bacterial growth in the hindgut of a marine deposit-feeder. Microb. Ecol. 18, 29-44.

Relexans, J.C., Deming, J., Dinet, A., Gaillard, J.F., Sibuet, M., 1996. Sedimentary organic matter and micro-meiobenthos with relation to trophic conditions in the tropical northeast Atlantic. Deep-Sea Res. 8, 1343-1368.

Rice, D.L., 1982. The detritus nitrogen problem: new observations and perspectives from organic geochemistry. Mar. Ecol. Prog. Ser. 9, 153162.

Riisgård, H.U., 1988. Efficiencyof particle retention and filtration rate in six species of Northeast American bivalves. Mar. Ecol. Prog. Ser. 45, 217223.

Soltwedel, T., Thiel, H., 1995. Biogenic sediment compounds in relation to marine meiofaunal abundances. Int. Rev. Gesamt. Hydrobiol. 80, 297311.

Webb, J.E., 1969. Biologically significant properties of submerged marine sands. Proc. R. Soc. Lond. Ser. B 174, 355-402.

Whitlatch, R.B., Weinberg, J.R., 1982. Factors influencing particle selection and feeding rate in the polychaete Cistenides (Pectinaria) gouldii. Mar. Biol. 71, 33-40. 